OPEN ACCESS

Edited by:

Carmen Gerlach,

Karolinska Institutet (KI), Sweden

Reviewed by:

Julie Ribot,

Instituto de Medicina Molecular (IMM),

Portugal

Tara Marlene Strutt, University of Central Florida,

United States

*Correspondence:

Brian S. Sheridan

brian.sheridan@stonybrook.edu

Specialty section:

This article was submitted to Immunological Memory,

a section of the journal

Frontiers in Immunology

Received: 05 September 2018

Accepted: 26 October 2018

Published: 27 November 2018

Citation:

Khairallah C, Chu TH and Sheridan BS (2018) Tissue Adaptations of Memory and Tissue-Resident Gamma Delta T Cells. Front. Immunol. 9:2636. doi: 10.3389/fimmu.2018.02636

\section{Tissue Adaptations of Memory and Tissue-Resident Gamma Delta T Cells}

\author{
Camille Khairallah, Timothy H. Chu and Brian S. Sheridan*
}

Department of Molecular Genetics and Microbiology, Center for Infectious Diseases, Stony Brook University, Stony Brook, NY, United States

Epithelial and mucosal barriers are critical interfaces physically separating the body from the outside environment and are the tissues most exposed to microorganisms and potential inflammatory agents. The integrity of these tissues requires fine tuning of the local immune system to enable the efficient elimination of invasive pathogens while simultaneously preserving a beneficial relationship with commensal organisms and preventing autoimmunity. Although they only represent a small fraction of circulating and lymphoid $T$ cells, $\gamma \delta T$ cells form a substantial population at barrier sites and even outnumber conventional $\alpha \beta T$ cells in some tissues. After their egress from the thymus, several $\gamma \delta$ T cell subsets naturally establish residency in predetermined mucosal and epithelial locations, as exemplified by the restricted location of murine $V_{\gamma} 5^{+}$and $\vee \gamma 3 V \delta 1+T$ cell subsets to the intestinal epithelium and epidermis, respectively. Because of their preferential location in barrier sites, $\gamma \delta T$ cells are often directly or indirectly influenced by the microbiota or the pathogens that invade these sites. More recently, a growing body of studies have shown that $\gamma \delta$ T cells form long-lived memory populations upon local inflammation or bacterial infection, some of which permanently populate the affected tissues after pathogen clearance or resolution of inflammation. Natural and induced resident $\gamma \delta T$ cells have been implicated in many beneficial processes such as tissue homeostasis and pathogen control, but their presence may also exacerbate local inflammation under certain circumstances. Further understanding of the biology and role of these unconventional resident $T$ cells in homeostasis and disease may shed light on potentially novel vaccines and therapies.

Keywords: memory $\gamma \delta$ T cells, resident $\gamma \delta$ T cells, innate $\gamma \delta$ T cells, adaptive $\gamma \delta$ T cells, barrier infections

\section{INTRODUCTION}

Epithelial and mucosal tissues form physical barriers separating the body from the outside world. They are constantly exposed to a wide range of stressors such as infectious agents and their toxins capable of damaging barrier tissues. Barrier surface interactions with microorganisms extend far beyond encounters with pathogenic microbes; indeed, these tissues are typically mutualistic ecosystems that maintain beneficial relationships for resident commensal organisms while providing support to the tissue (1). Because of the complexity of these interfaces, the immune system is tightly regulated in order to eliminate invading pathogens while maintaining a robust commensal environment. It is now well established that the microbiota plays a significant role in 
educating immune cells and promoting protective anti-infectious responses (2-4). However, the microbiota may also play an important role in aberrant inflammation $(5,6)$. In addition, pathogenic agents also leave their imprint on the immune system and generate long-lasting memory responses. Protective immunity has mainly been the purview of conventional effector memory $\left(\mathrm{T}_{\mathrm{EM}}\right)$ or central memory $\left(\mathrm{T}_{\mathrm{CM}}\right) \mathrm{T}$ cells and $\mathrm{B}$ cells. More recently, the discovery of conventional resident memory $\mathrm{T}$ cells $\left(\mathrm{T}_{\mathrm{RM}}\right)(7,8)$, innate immune memory also known as trained immunity $(9,10)$, and other unconventional memory responses $(11,12)$ has focused attention on tissue-specific immunity at barrier locations.

$\gamma \delta$ T cells are an unconventional T cell population that display immunologic features common to both the innate and adaptive immune systems (13). This dual nature of $\gamma \delta \mathrm{T}$ cell biology is typified by their non-MHC-restricted antigenic specificity while mounting rapid immune responses to a wide range of tissue stressors (14), generally referred to as "lymphoid-stress surveillance" (15). $\gamma \delta \mathrm{T}$ cells are the first T cells generated during embryonic development and quickly seed peripheral tissues where specialized subsets are maintained for life in residence. These unconventional $\mathrm{T}$ cells are only found at low frequencies in lymphoid tissues and the blood in adult humans and rodents; however, they are enriched in epithelial and mucosal tissues (16-19). Generally, distinct barrier tissues harbor mostly nonoverlapping $\gamma \delta \mathrm{T}$ cell subsets with non-redundant functions (17). Some tissues contain unique and highly specialized $\gamma \delta$ $\mathrm{T}$ cell subsets that are not found elsewhere in the body. For example, $\mathrm{V} \gamma 3 \mathrm{~V} \delta 1^{+}$skin dendritic epidermal $\mathrm{T}$ cells (DETC) reside exclusively in the skin epidermis while $\mathrm{V} \gamma 5^{+} \mathrm{T}$ cells reside exclusively in the intestinal epithelium [the Garman nomenclature (20) is used throughout this review for murine $\gamma \delta \mathrm{T}$ cells] (21). The development and selection processes that regulate the differentiation of these cells are unique and result in the generation of highly adapted cells that actively survey neighboring cells, sense and respond to stresses of various nature and participate in many tissue processes. Thus, these natural tissue-resident $\gamma \delta \mathrm{T}$ cells are programmed sentinels that are also shaped by and highly adapted to their tissue environment.

Because of their preferential location in barrier sites, $\gamma \delta \mathrm{T}$ cells are often directly or indirectly influenced by the microbiota or the pathogens that invade these sites. The steady-state microbiota may influence the generation, effector functions, or maintenance of $\gamma \delta$ T cells (22-24). These commensal-induced $\gamma \delta \mathrm{T}$ cells adapt to their tissue of residence where they add another level of immune surveillance and may be mobilized in many pathological contexts including inflammation (25-27) and cancer $(28,29)$. These tissue-resident $\gamma \delta \mathrm{T}$ cells are also mobilized during infection to promote anti-pathogen immunity (30) and represent innate first responders during infection. Alternatively, pathogeninduced adaptive $\gamma \delta$ T cells appear to follow a more conventional $\mathrm{T}$ cell maturation pathway, resulting in delayed activation and expansion while favoring the establishment of long-lasting memory and heightened protective potential upon pathogen reexposure. Throughout this review, the term "adaptive" will be utilized to describe $\gamma \delta \mathrm{T}$ cells having features consistent with conventional $\alpha \beta \mathrm{T}$ cells. This review will focus on the tissue adaptation of tissue-resident natural $\gamma \delta \mathrm{T}$ cells and adaptive $\gamma \delta$ $\mathrm{T}_{\mathrm{RM}}$ cells in barrier tissues while highlighting their development, maintenance and role in health and disease.

\section{$\gamma \delta$ T CELLS OF HUMANS AND MICE}

Murine $\gamma \delta \mathrm{T}$ cells are often segregated into different subsets based on their $\mathrm{V} \gamma \mathrm{T}$ cell receptor (TCR) chain, as it is generally associated with tissue tropism and a bias in effector function $(31,32)$ (Table 1). It is well established that $\gamma \delta \mathrm{T}$ cell ontogeny is temporally controlled and manifested by "waves" of development (76). The factors regulating $\gamma \delta \mathrm{T}$ cell development have been recently reviewed $(77,78)$. Most barrier tissue $\gamma \delta \mathrm{T}$ cells develop early during fetal development in the fetal/neonatal thymus with the first thymic wave of $\gamma \delta \mathrm{T}$ cells starting at embryonic day 13 and giving rise to DETC characterized by surface expression of an invariant $\mathrm{V} \gamma 3 \mathrm{~V} \delta 1$ TCR (16). $\mathrm{V} \gamma 3 \mathrm{~V} \delta 1^{+}$DETC migrate to the skin epidermis $(18,76,79)$ and produce IFN $\gamma(80)$ and other cytokines $(81,82)$, and growth factors $(83,84)$. From embryonic day 14 to the perinatal period, the fetal/neonatal thymus generates other innate-like [also called "natural" (85)] $\gamma \delta$ $\mathrm{T}$ cells, including the IL-17A biased quasi-invariant $\mathrm{V} \gamma 4 \mathrm{~V} \delta 1^{+} \mathrm{T}$ cells which preferentially migrate to the genital tract, the tongue and the lungs $(16,76,86)$. Fetal-derived $\gamma \delta \mathrm{T}$ cells are typically considered innate-like due to their reduced TCR sensitivity (87) and rapid functional response to innate stimuli like cytokines and pathogen- or danger-associated molecular patterns $(72,88,89)$. IL-17A-producing $\gamma \delta \mathrm{T}$ cells (referred to as $\gamma \delta 17 \mathrm{~T}$ cells in this review) are characterized by the expression of the transcription factor ROR $\gamma$ t (90), chemokine receptor CCR6 (86, 90, 91), scavenger receptor SCART2 (92), CD25 (93), but lack CD27 $(86,90,94)$. In contrast, IFN $\gamma$-producing $\gamma \delta \mathrm{T}$ cells express the transcription factor T-bet and surface receptors NK1.1 and CD27. Consistent with other IFN $\gamma$ producing lymphocytes, they also express high levels of the IL-2/IL-15 receptor $\beta$ chain CD122 $(93,95)$. It was initially thought that $\gamma \delta 17 \mathrm{~T}$ cells acquired their peripheral effector fate due to a lack of antigenic selection in the thymus; antigen-experienced cells were programmed to make IFN $\gamma$ in the periphery while antigen-inexperienced cells were programmed to make IL-17A $(80,87,95,96)$. However, recent evidence suggests that signaling through the TCR is required for $\gamma \delta 17 \mathrm{~T}$ cells development and that the strength of the signal is the critical factor determining their functional lineage. A strong TCR signal promotes an IFN $\gamma$-dominant lineage whereas a weak TCR signal promotes an IL-17A-dominant lineage (97-99). An additional level of regulation comes from the thymic cytokine milieu: while signaling through IL-15R $\alpha$ restrains $\gamma \delta 17 \mathrm{~T}$ cell development in cis (100), IL-7 promotes their expansion (101). An interesting feature of $\gamma \delta 17 \mathrm{~T}$ cells is their functional plasticity, which allows them to co-produce IL-17A and IFN $\gamma$ under certain circumstances $(61,102)$. Although $\mathrm{CD}^{-} 7^{-} \gamma \delta \mathrm{T}$ cells have a permissive chromatin state at the Ill7a and Ifng loci, only a handful of situations have been associated with IL-17A and IFN $\gamma$ co-production in vivo, including oral Listeria monocytogenes (L. monocytogenes) infection $(61,62)$ and peritoneal tumor (102). Post-transcriptional repression of IFN $\gamma$ production has 
TABLE 1 | Memory and tissue resident $\gamma \delta$ T cells in infection and disease.

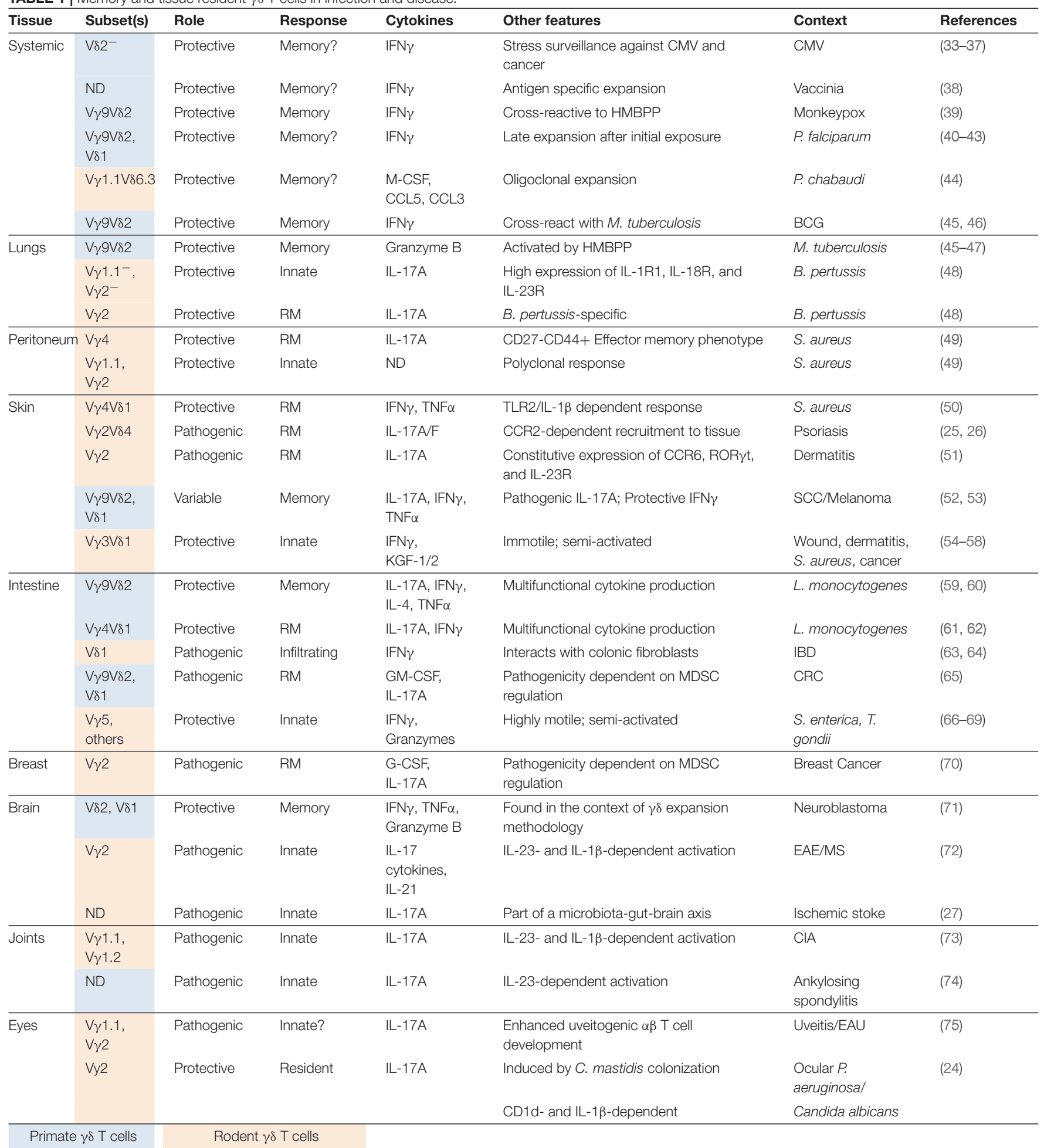

ND, not determined; RM, resident memory; CMV, cytomegalovirus; BCG, M. bovis BCG strain; SCC, squamous cell carcinoma; IBD, inflammatory bowel disease; CRC, colorectal cancer; EAE/MS, experimental autoimmune encephalomyelitis/multiple sclerosis; CIA, collagen-induced arthritis; EAU, experimental autoimmune uveitis. 
recently been reported in $\gamma \delta 17 \mathrm{~T}$ cells (61); however, whether coproduction of IL-17A and IFN $\gamma$ is regulated by derepression has not been evaluated.

Although most $\gamma \delta 17 \mathrm{~T}$ cells fall into the innate-like category, adaptive-like differentiation of naïve $\gamma \delta \mathrm{T}$ cell precursors into mature $\gamma \delta 17 \mathrm{~T}$ cells in peripheral lymphoid organs has also recently been reported in multiple models. After the identification of phycoerythrin (PE) as a $\gamma \delta$ TCR antigen, PEspecific $\gamma \delta$ T cells were shown to transition from a naïve CD $44^{\text {lo }}$ CD62L ${ }^{\text {hi }}$ to an activated $\mathrm{CD} 44^{\text {hi }}$ CD62 $\mathrm{L}^{\text {lo }}$ phenotype after immunization with PE (103). These $\gamma \delta \mathrm{T}$ cells expressed ROR $\gamma \mathrm{t}$ and inflammatory cytokine receptors IL-1R1 and IL-23R which drove production of IL-17A without extensive proliferation (103). Similarly, imiquimod (IMQ)-induced skin inflammation and MOG-induced experimental autoimmune encephalomyelitis (EAE) induced the de novo generation of $\gamma \delta 17 \mathrm{~T}$ cells in draining lymph nodes $(104,105)$. These unrelated models demonstrate that the differentiation of some $\gamma \delta 17 \mathrm{~T}$ cell subsets is optimal with a TCR signal and in the presence of IL-23, reminiscent of the multistep development of naïve $\mathrm{CD} 4^{+} \mathrm{T}$ cells. In contrast to natural $\gamma \delta 17 \mathrm{~T}$ cells, these de novo generated cells are often referred to as inducible $\gamma \delta 17 \mathrm{~T}$ cells (14).

$\gamma \delta \mathrm{T}$ cell subsets in human and non-human primates are generally divided into two major populations based on the $\mathrm{V} \delta$ TCR chain: $\mathrm{V} \delta 2^{+}$and $\mathrm{V} \delta 2^{-} \gamma \delta \mathrm{T}$ cells. $\mathrm{V} \delta 2^{+} \mathrm{T}$ cells appear to develop almost exclusively in the fetal liver and fetal thymus $(106,107)$ and form the predominant $\gamma \delta \mathrm{T}$ cell population in the peripheral blood of adult humans $(108,109)$. Most fetal, cord blood and adult $\mathrm{V} \delta 2^{+} \mathrm{T}$ cells express the semiinvariant $\mathrm{V} \gamma 9 \mathrm{~V} \delta 2 \mathrm{TCR}$ with a public germline encoded CDR3 $\gamma$ sequence and a more diverse CDR $3 \delta$ sequence (110). Despite their preferential localization in the blood, $\mathrm{V} \gamma 9 \mathrm{~V} \delta 2^{+} \mathrm{T}$ cells can also be recruited to inflamed tissues where they can participate in pathogen clearance or promote inflammation $(39,45,47)$ (Table 1). The TCR combination allows the majority of $\mathrm{V} \gamma 9 \mathrm{~V} \delta 2^{+}$ $\mathrm{T}$ cells to recognize prenyl pyrophosphate metabolites (111), broadly referred to as phosphoantigens (PAgs), presented in the context of butyrophilin (BTN)3A1 and BTN3A2 (112-115). PAgs are metabolic intermediates produced by the eukaryotic mevalonate pathway and the microbial 2-C-methyl-D-erythriol 4-phosphate (MEP) pathway, which generates one of the most potent $\mathrm{V} \gamma 9 \mathrm{~V} \delta 2^{+} \mathrm{T}$ cell activator (E)-4-hydroxy-3-methyl-but2 -enyl pyrophosphate (HMBPP) (111). Fetal V $\gamma 9 \mathrm{~V} \delta 2^{+} \mathrm{T}$ cells express genes found in adult cells and can expand and produce IFN $\gamma$ in response to HMBPP stimulation (110). By 1 year of age, almost all $\mathrm{V} \gamma 9 \mathrm{~V} \delta 2^{+} \mathrm{T}$ cells have acquired a memory phenotype and can rapidly produce IFN $\gamma$ and cytotoxic molecules (108, 116), similar to circulating adult cells $(108,116,117)$. These data suggest that human $\mathrm{V} \gamma 9 \mathrm{~V} \delta 2^{+} \mathrm{T}$ cells are preprogrammed fetal-derived effectors with a restricted TCR specificity. Thus, $\mathrm{V} \gamma 9 \mathrm{~V} \delta 2^{+} \mathrm{T}$ cells seem to belong to the natural, innate-like population of lymphocytes.

In contrast to $\mathrm{V} \gamma 9 \mathrm{~V} \delta 2^{+} \mathrm{T}$ cells, the $\mathrm{V} \delta 2^{-} \gamma \delta \mathrm{T}$ cell subset is heterogenous (106) and preferentially resides in epithelial tissues such as the skin (118) and intestines (119) and appears to form resident populations in the liver (120) (Table 1). V $\delta 2^{-}$ $\gamma \delta \mathrm{T}$ cells mainly consist of $\mathrm{V} \delta 1^{+} \mathrm{T}$ cells, with fewer $\mathrm{V} \delta 3^{+}$and
$\mathrm{V} \delta 5^{+} \mathrm{T}$ cells. While most antigens recognized by $\mathrm{V} \delta 2^{-} \gamma \delta \mathrm{T}$ cells remain unknown, the antigens identified to date suggest a broad reactivity to MHC-like molecules like endothelial protein C receptor (EPCR) (33) and CD1 molecules $(33,121,122)$, stressinduced ligands (123) and algal phycoerythrin (103). V $\delta 2^{-} \gamma \delta \mathrm{T}$ cell TCR are highly diverse in cord blood but their TCR repertoire becomes more restricted into adulthood (124). Furthermore, they clonally expand in response to cytomegalovirus (CMV) infection and differentiate into $\mathrm{CD}_{4} 5 \mathrm{RA}^{+}$effector memory $\mathrm{T}$ ( $\left.\mathrm{T}_{\text {EMrA }}\right)$ cells $(34,35,125-127)$. Thus, the $\mathrm{V} \delta 2^{-} \gamma \delta \mathrm{T}$ cell repertoire appears to be shaped by TCR-dependent selection events mediated by microbial encounters throughout life. As $\mathrm{V} \delta 2^{-} \gamma \delta \mathrm{T}$ cells can recognize stress antigens, non-infectious events that trigger a response, such as cancer development, may also shape their repertoire $(36,128)$.

$\gamma \delta \mathrm{T}$ cells can provide different physiologic roles depending on the nature and context of the insult, the tissue involved and the $\gamma \delta \mathrm{T}$ cell populations mobilized. At steady state, $\gamma \delta \mathrm{T}$ cells are involved in many biological processes aiming at maintaining barrier integrity (e.g., by promoting epithelial cell survival and homeostasis) $(82-84,129)$ and regulating thermogenesis (130). Because of their rapid sensing of stress and recruitment to inflamed sites, $\gamma \delta \mathrm{T}$ cells are often involved in shaping early immunologic events. They can promote the activation, maturation, and recruitment of dendritic cells (DC), neutrophils, $\mathrm{B}$ cells, and conventional $\mathrm{T}$ cells [for a detailed review see (131)]. $\gamma \delta \mathrm{T}$ cells are also a direct and potent source of critical inflammatory cytokines like IFN $\gamma$, TNF $\alpha$ and IL-17A in many pathological contexts, including infection $(59,111,132-134)$, autoimmune disease $(25,26,72,135)$ and cancer $(29,136-$ 138). As such, they are also an integral part of the effector response. At later phases, $\gamma \delta \mathrm{T}$ cells can promote the resolution of the inflammation through the production of anti-inflammatory molecules like $\operatorname{TGF} \beta(139,140)$. Finally, they sustain tissue repair and remodeling after infection or injury $(54,83,132,141)$. Thus, $\gamma \delta \mathrm{T}$ cells are critically involved in regulating health during homeostasis and disease.

\section{THE FIRST TISSUE-RESIDENT T CELLS: INTESTINAL AND EPIDERMAL $\gamma \delta$ T CELLS}

Many $\gamma \delta \mathrm{T}$ cell subsets are constrained to specific tissue locations. DETC and intestinal intraepithelial lymphocytes (IEL) with a $\gamma \delta$ TCR $(\gamma \delta$ IEL) populate the two largest interfaces of the body, the skin and the intestines, respectively. DETC and $\gamma \delta$ IEL are shaped within their respective tissues where they provide adapted support to maintain tissue homeostasis and respond to stresses or invading pathogens. These populations have recently been the focus of an in-depth review (21). Thus, only features relevant to this review will be discussed here.

\section{Dendritic Epidermal T Cells- DETC}

DETC are the first $\mathrm{T}$ cells to develop during embryogenesis and by far the most abundant $\mathrm{T}$ cell subset present in the mouse skin epidermis (142). Their name stems from the unique DClike morphology observed during homeostasis. DETC form a 
highly uniform population characterized by the expression of a canonical $\mathrm{V} \gamma 3 \mathrm{~V} \delta 1$ TCR with no junctional diversity. The mouse fetal thymus supports the generation of the entire DETC precursor pool between embryonic day 13 and 18, after which mature DETC are maintained life-long in the skin epidermis by self-renewal $(18,76,79,143)$. The narrow developmental window of DETC progenitors may result from the temporally restricted expression of a Btn-like protein, Skint-1, by embryonic medullary thymic epithelial cells (144-146). Expression of Skint1 is required at various stages of DETC thymic development to regulate their biology. First, Skint-1 promotes the thymic maturation of $\mathrm{V} \gamma 3 \mathrm{~V} \delta 1^{+} \mathrm{T}$ cell progenitors, without which the skin epidermis would be devoid of mature DETC (144-146). Second, Skint-1 educates DETC precursors by promoting IFN $\gamma$ production over IL-17A (80), instructing skin-homing (147), and attenuating TCR responsiveness by increasing its activation threshold (87). Similarly, TCR signaling seems required for the maturation of DETC precursors (148-150) and the establishment of a mature population with innate-like properties in the skin epidermis $(87,148-151)$. It is also indirectly involved in the thymic egress and subsequent migration to the skin of positively selected progenitor cells. Indeed, TCR signaling induced the expression of sphingosine-1-phosphate receptor 1 (S1P1) and the skin-homing chemokine receptor CCR10, which mediates T cell exit from the thymus and migration toward keratinocytederived CCL27, respectively $(152,153)$. Additional molecules like E- and P-selectin ligands and CCR4 may also play a role in the establishment or maintenance of the DETC population in the skin (154).

During homeostasis, mature DETC are maintained in a semiactivated state and constantly survey the epidermis through the extension of motile basal dendrites and by projecting dendrites toward the apical epidermis. These dendrites establish stable synapses at the squamous keratinocyte junctions that allows DETC to survey several surrounding cells simultaneously (155). Each apical dendrite ends with phosphorylated tyrosine-rich aggregates in synapse-like structures enriched with TCR and phosphorylated TCR signaling intermediates. Therefore, mature DETC might receive continuous TCR-mediated signals from neighboring cells residing in the epidermis, which are necessary for their long-term maintenance in the tissue (156). Although healthy skin does not appear to express DETC TCR ligand detectable by soluble V $\gamma 3 \mathrm{~V} \delta 1$ TCR tetramers (157), exposure of the skin to low grade stresses might sustain basal expression of ligands sufficient for their survival but below the sensitivity of this detection method. Indeed, DETC express basal levels of the type- 2 cytokine IL-13 in resting skin, consistent with some level of activation at steady state (82). Absence of DETC-derived IL13 induces an epithelial cell stress response that disrupts barrier integrity. As such, DETC play a key role in preserving skin homeostasis at steady state.

The skin is constantly exposed to a variety of pathological conditions and stresses. Superficial damage to the epithelium induces a stress response associated with upregulation of the NKG2D ligand Rae-1 and leads to the further activation of DETC $(82,158)$. Enhanced production of DETC-derived IL13 induces keratinocyte maturation, which promotes efficient epithelial cell renewal, restoring tissue integrity (82). Shortly after deep wounding, damaged keratinocytes in close proximity to the lesion quickly and transiently upregulate a yet unidentified stress antigen $(156,157,159)$. DETC rapidly become activated in a TCR dependent-manner and their activation is associated with retraction of their dendrites and cellular rounding $(54,155,159)$. Full activation of DETC in this context requires engagement of the TCR and costimulation provided by the junctional adhesion molecule JAML (81), CD100 (semaphorin-4D) (160) or NKG2D $(161,162)$, whose ligands are all upregulated in damaged skin. Activated DETC provide anti-apoptotic signals to keratinocytes and promote their survival through the production of insulin-like growth factor-1 (84). DETC also produce many additional growth factors, including keratinocyte growth factor (KGF)-1 and $\operatorname{KGF}^{2}$ (54, 83), inflammatory cytokines like $\operatorname{IFN} \gamma$ and $\operatorname{TNF} \alpha(81,163)$ and chemokines (164) that favor epithelial regeneration and wound closure. The important and non-redundant contribution of DETC to wound repair was demonstrated in $\mathrm{Tcrd}^{-/-}$mice or animals deficient in DETC costimulatory signals. Lack of DETC or their impaired activation led to a substantially delayed wound healing (54, 81, 160-162). Additional roles of DETC include regulation of aberrant inflammation in a model of contact dermatitis (55) and protection against UV-mediated DNA damage (165), cutaneous infection (56) and development of malignancies $(57,58,166)$. Interestingly, DETC may mediate their anti-cancer effect by direct cytolytic activity in a TCR- and NKG2D-dependent manner in vitro (57). Additionally, IL-13 production by DETC favors the production of $\operatorname{IgE}$ (158), that promotes protective anti-cancer immunity through a yet undetermined mechanism involving tumor infiltrating Fce RI ${ }^{+}$cells (166).

Mucosal and epithelial sites are not only patrolled by natural resident cells like DETC, they are also kept under the surveillance of pathogen-induced $\mathrm{CD}^{+}$and $\mathrm{CD}^{+} \alpha \beta \mathrm{T}_{\mathrm{RM}}$ cells which provide local long-lived protection against reinfection $(7,8)$. Natural and induced resident $\mathrm{T}$ cells occupy a similar space. Cutaneous infection by herpes simplex virus (HSV) generates $\mathrm{CD}^{+} \mathrm{T}_{\mathrm{RM}}$ that remain in the basal epidermis around the lesion site $(167,168)$. Surprisingly, the increased $\mathrm{CD}^{+} \mathrm{T}_{\mathrm{RM}}$ density at the site of infection inversely correlated with DETC numbers even several months after pathogen clearance. Conversely, distant DETC-rich areas had a reduced $\mathrm{CD} 8^{+} \mathrm{T}_{\mathrm{RM}}$ population. One potential explanation for the redistribution of resident $\mathrm{T}$ cell subsets is that infection may lead to selective loss of DETC, creating a niche for $\mathrm{CD}^{+} \mathrm{T}_{\mathrm{RM}}$ cell seeding. Indeed, DETC are rapidly infected by HSV after cutaneous exposure (169). HSV infection of non-neuronal cells is typically lytic and may induce their death. However, alternative mechanisms may also lead to loss of DETC as their redistribution was also observed after intradermal injection of effector $\mathrm{CD} 8^{+} \mathrm{T}$ cells in the absence of infection (168). DETC can also be temporarily displaced by infiltrating NKT cells following acute stress (58), demonstrating that conventional and unconventional $\alpha \beta$ T cells can colonize the skin and create a niche at the expense of DETC. It has been proposed that these cells may compete for maintenance signals like IL-15 or aryl hydrocarbon receptor (AhR) ligands (170), which are necessary for mature DETC 
survival in the skin (171-174). Such competition should also occur between $\alpha \beta \mathrm{T}_{\mathrm{RM}}$ generated by different, non-overlapping infections as both populations would be expected to have similar homeostatic requirements. However, it was recently reported that the generation of new $\alpha \beta \mathrm{T}_{\mathrm{RM}}$ cells does not result in the replacement of previously established $\mathrm{T}_{\mathrm{RM}}$ cells (175), suggesting that limited resources like IL-15 may not be responsible for redistribution of DETC and $\alpha \beta \mathrm{T}_{\mathrm{RM}}$ cells. Identifying the factors involved in the maintenance of natural and induced $\mathrm{T}$ cell populations is necessary to better understand their apparent competition and would be beneficial for the design of targeted local therapies.

\section{Intestinal Intraepithelial Lymphocytes $-\gamma \delta$ IEL}

The intestinal epithelium is actively patrolled by IEL, a large fraction of which are unconventional $\gamma \delta \mathrm{T}$ cells expressing a CD8 $\alpha \alpha$ homodimer in mice $(19,176)$. The intestine is colonized by $\gamma \delta$ IEL during the perinatal period. In contrast to the essential role of the thymus in the generation other $\gamma \delta \mathrm{T}$ cell subsets, its contribution to intestinal $\gamma \delta$ IEL development is more limited. Intestinal $\gamma \delta$ IEL can develop extrathymically in athymic mice but at lower numbers than in euthymic animals (177-180). IL7 production has been shown to be fundamental for $\gamma \delta$ IEL thymic and extrathymic intestinal development $(181,182)$. A large fraction of $\gamma \delta$ IEL express the $\operatorname{V~} \gamma 5 \operatorname{TCR}(79,183)$. The preferential expression of $\mathrm{V} \gamma 5$ is controlled at the chromatin level by IL-15-STAT5 signals, which regulate the accessibility of the $\mathrm{V} \gamma 5$ gene and favor its expression in thymocytes and immature IEL (184). Despite the overrepresentation of the $\mathrm{V} \gamma 5$ TCR among $\gamma \delta$ IEL, the overall $\gamma \delta$ TCR repertoire in the intestinal epithelium is diverse. Indeed, several mechanisms contribute to the diversity of intestinal $\gamma \delta$ IEL including various $\mathrm{V} \delta$ and $\mathrm{V} \gamma$ chain pairings, usage of the $J \delta 1$ or $J \delta 2$ segment and addition of non-germline encoded nucleotides $(79,183)$. Because of their TCR heterogeneity, $\gamma \delta$ IEL have the potential to recognize a wide array of potential antigens or ligands that include host-derived molecules such as nonclassical and nonpolymorphic MHC class Ib molecules T10 and T22 (185). Despite the similarity to MHC class I molecules, T10 and T22 do not present peptide antigens. T10/T22 reactivity is conferred by a specific W-(S)EGYEL CDR3 3 motif, which allows some ${\mathrm{V} \gamma 5^{+}}^{+} \mathrm{V} \gamma 1.1^{+}$and $\mathrm{V} \gamma 2^{+} \gamma \delta$ IEL to bind T10/T22 (185). To date, the antigenic specificity of the non-T10/T22 reactive $\gamma \delta$ IEL remains obscure.

$\gamma \delta$ IEL precursors do not require S1P1 for their emigration from the thymus (186). However, $\gamma \delta$ thymocytes and unconventional $\left(\mathrm{CD} 8 \alpha \alpha^{+}\right)$recent thymic emigrants express high levels of the gut homing receptors CCR9 $(187,188)$ and $\alpha_{4} \beta_{7}$ integrin (187-189). Interestingly, CCR9 is preferentially expressed by antigen-inexperienced $\mathrm{CD} 122^{\text {lo }}$ or $\mathrm{CD} 62 \mathrm{~L}^{\mathrm{hi}}$ CD44 $4^{\text {int/lo }}$ thymocytes $(189,190)$, suggesting they have more potential to home to the gut and that some $\gamma \delta$ IEL did not encounter their antigen prior to their migration into intestinal tissues. This assumption was confirmed by the presence of similar numbers of T10/T22 reactive $\gamma \delta \mathrm{T}$ cells in the intestinal epithelium of $\mathrm{B}^{2} \mathrm{~m}^{-/-}$mice, which lack surface expression of
T10/T22 (190). Intestinal $\gamma \delta$ IEL might be selected based on their TCR affinity more than their specificity, as suggested by the inverse correlation between TCR affinity and CCR9 expression (190). This unusual "non-selection" of a diversified $\gamma \delta$ T cells likely reflects the need to maintain a heterogeneous broadly reactive population that can respond appropriately to the wide variety of stresses and antigens encountered in the intestine.

Within the first few weeks of life, ${\mathrm{V} \gamma 5^{+}}^{+} \mathrm{T}$ cells expand in the intestinal epithelium and transition from an immature to a mature phenotype (180). Despite the heavy microbial colonization of the gut, $\gamma \delta$ IEL expansion and maturation are independent of the microbiota $(66,178)$. Instead, expansion and maturation are regulated in a TCR-dependent manner by the BTN-like (Btnl)1 and Btnl6 heterocomplex expressed on the surface of enterocytes (180), reminiscent of Skint-1mediated selection of DETC in the thymus (144-146). Upon selection by cells co-expressing Btnl1 and Btnl6, $\mathrm{V} \gamma 5^{+} \mathrm{T}$ cells upregulate $\mathrm{CD} 25$ and produce pro-inflammatory cytokines like IFN $\gamma$, growth factors like GM-CSF and chemokines like CCL4 (180). The Btnl-mediated selection of intestinal $\gamma \delta$ IEL may occur in a similar fashion in humans, with $\mathrm{V} \gamma 4^{+} \mathrm{T}$ cells being activated by cells co-expressing BTNL3 and 8 (180). Once established in the tissue, $\gamma \delta$ IEL rely on the production of IL- 15 by microbiota stimulated intestinal epithelial cell (IEC) (191-193) and AhR ligands (174) for their maintenance and survival. In return, $\gamma \delta$ $\mathrm{T}$ cells participate in the maintenance of tissue homeostasis and barrier integrity. $\gamma \delta$ IEL promote IEC proliferation and maturation through multiple mechanisms that may include production of $\operatorname{KGF}(83,129,141)$, regulating tight junctions (67), producing anti-microbial peptides in response to pathobiont invasion (68), limiting tissue damage, and promoting epithelial repair after injury (141).

$\gamma \delta$ IEL from specific pathogen-free (SPF) mice constitutively express cytotoxic genes, including granzyme A and B (194), and can lyse target cells directly ex vivo (195), consistent with an anti-infectious role of intestinal $\gamma \delta$ IEL. The absence of $\gamma \delta \mathrm{T}$ cells in $\mathrm{Tcrd}^{-/-}$was associated with enhanced dissemination of enteric bacteria (Salmonella enterica serovar Typhimurium) or parasites (Toxoplasma gondii), rendering mice more susceptible to systemic infection (67-69). Additionally, $\gamma \delta$ IEL indirectly protect from murine norovirus infection by secreting type I and III interferons and increasing the resistance of IEC to viral infection (196). They are also important in controlling dissemination of commensals that may occur with loss of barrier integrity after pathogen invasion or epithelial injury (197). Thus, $\gamma \delta$ IEL serve multiple functions in regulating immunity at the mucosal interface with the environment.

Intestinal $\gamma \delta$ IEL were initially thought to have limited mobility within the epithelium (188). This view has recently been challenged by two compelling studies that demonstrated that intestinal $\gamma \delta$ IEL are highly dynamic and constantly migrate within the intestinal tissue. During tissue homeostasis, individual $\gamma \delta$ IEL survey a large surface area and contact numerous IEC within a short period of time $(66,198) . \gamma \delta$ IEL mainly remain in the middle region of the intestinal villi, between the basement membrane and the epithelial layer, but they also appear to occasionally migrate to the intercellular space between IEC for 
a short period of time $(66,198)$. Although commensals do not impact $\gamma \delta$ IEL numbers, microbial colonization is required for their normal distribution within the villi and their migratory behavior in the tissue (66), and also promotes their cytotoxic and anti-microbial functions $(68,195)$. These patterns drastically change upon enteric infection with invasive bacteria or parasites. Shortly after pathogenic exposure, $\gamma \delta$ IEL preferentially localized to pathogen-rich areas and decreased their normal surveillance behavior. Reduced surveillance coverage was associated with increased movement between IEC and the lateral intercellular space in a behavior termed "flossing" $(66,69)$ that is regulated by the tight junction protein occludin (198). These behavioral and functional changes result from the MyD88-dependent sensing of pathogenic microbes by IEC, and the specific abrogation of MyD88 signaling in IEC severely blunted $\gamma \delta$ IEL responses $(66,68) . \gamma \delta$ IEL at steady-state may also be activated through their TCR as injection of a TCR $\delta$-specific antibody diminished intracellular calcium flux (199). It is therefore conceivable that the IEC- $\gamma \delta$ IEL dialogue could also involve TCR-mediated tissue surveillance. Thus, $\gamma \delta$ IEL continually survey epithelial integrity via cross-talk with IEC which dictates $\gamma \delta$ IEL behavior and leads to their adaptation in the intestinal environment. While the exact function of $\gamma \delta$ IEL flossing remains unclear, its association with pathogen hotspots and the importance of $\gamma \delta \mathrm{T}$ cell responses to anti-infection immunity suggests an important role of flossing in controlling intestinal infections or promoting epithelial repair.

Natural tissue-resident $\gamma \delta \mathrm{T}$ cells are remarkably adapted to their tissue of residence, where they provide signals necessary to maintain tissue homeostasis and barrier integrity while also providing a rapid front-line defense against infectious assaults continually encountered in epithelial tissues. Both DETC and intestinal $\gamma \delta$ IEL are adapted to efficiently survey their respective tissues, through their placement/migration into the tissue and communication with neighboring epithelial and immune cells. Despite this, natural tissue-resident $\mathrm{T}$ cells may have to compete for limited space or nutrients with de novo generated conventional $\mathrm{T}_{\mathrm{RM}}$ cells after local infections. Whether direct competition for resources and space or an undefined crosstalk between these cells regulate tissue colonization is unclear and an area of much interest.

\section{MICROBIOTA-INDUCED $\gamma \delta 17 \mathrm{~T}$ CELLS: DIVERSIFIED EFFECTORS WITH MULTIFACETED ROLES}

Almost all tissues exposed to the environment are colonized by established commensal communities, with the exception of the eye for which the presence of a resident microbiome remains a matter of debate (1). The presence of these microorganisms shapes the local immune system and promotes protective anti-infectious immunity, as exemplified by the anti-bacterial, -fungal or -parasitic type-17 and type-1 responses triggered by segmented filamentous bacteria in the intestines (2) or Staphylococcus epidermidis (S. epidermidis) and other commensals in the skin $(3,4)$, respectively. However, commensal-specific $\mathrm{T}$ cells (especially intestinal $\mathrm{T}_{\mathrm{H}} 17$ cells) can also have detrimental effects at remote sites under certain circumstances, inducing pathological inflammatory responses that lead to the development of diseases like arthritis and autoimmune encephalomyelitis $(5,6)$.

As for conventional T cells, the microbiota also impacts $\gamma \delta$ $\mathrm{T}$ cell responses at many body sites. Interestingly, commensalinduced $\gamma \delta \mathrm{T}$ cell responses appear to largely involve IL-17Aproducing cells regardless of their tissue distribution among diverse sites such as the skin $(4,200)$, the liver (22), the oral and peritoneal cavities $(23,201)$, the eye (24), the lungs (28) and the intestines $(29,197)$. The generation and activation requirements of microbiota-induced $\gamma \delta \mathrm{T}$ cells appear uniquely adapted to the tissue location. First of all, the presence of a microbiota is a prerequisite for the development of some, but not all, tissue tropic $\gamma \delta \mathrm{T}$ cells. Indeed, antibiotic-treated SPF or germ-free (GF) mice harbor fewer activated liverresident (22), pulmonary (28), peritoneal, and small intestinal lamina propria (siLP) $\gamma \delta 17 \mathrm{~T}$ cells (23). In contrast, $\gamma \delta$ IEL numbers are independent of a microbiota $(66,178,197)$. Second, few identified microorganisms have been specifically associated to particular $\gamma \delta \mathrm{T}$ cell populations: Corynebacterium mastidis (C. mastidis) colonization with ocular $\mathrm{V} \gamma 2^{+} \gamma \delta 17 \mathrm{~T}$ cells (24), Corynebacterium accolens (C. accolens) and other bacteria from the Corynebacterium genus producing mycolic acid with skin $\mathrm{V} \gamma 2^{+} \gamma \delta 17 \mathrm{~T}$ cells, and $S$. epidermidis with skin $\mathrm{V} \gamma 2^{-} \gamma \delta 17 \mathrm{~T}$ cells (200). The expansion of $\mathrm{V} \gamma 2^{+}$and $\mathrm{V} \gamma 2^{-}$ $\gamma \delta \mathrm{T}$ cell subsets by $C$. accolens and $S$. epidermidis association, respectively, demonstrates that the $\gamma \delta \mathrm{T}$ cell responses can adapt within the same niche. In contrast, other $\gamma \delta \mathrm{T}$ cell subsets only require the presence of a microbiota without any distinction between bacterial species $(22,28)$. Lastly, many different signals control the activation and/or expansion of commensal-induced $\gamma \delta 17 \mathrm{~T}$ cells, including lipid presentation by the non-classical molecule CD1d (22), DC-mediated expansion $(24,201)$ and activation/polarization $(27,29,200)$ or MyD88 signaling pathways $(23,197)$. Cytokines like IL-1 $\beta(23,24)$, IL23 (200) and IL-6 (28), either alone or in combination with other activation signals, also participate in the induction or propagation of IL-17A from microbiota-induced $\gamma \delta \mathrm{T}$ cells.

IL-17 family cytokines, including IL-17A, are key regulators of mucosal and epithelial immunity. Over the past decade, a multitude of roles, from the induction of protective anti-infectious responses to the promotion of pathological inflammatory processes, have been attributed to IL-17A (202). Accordingly, the induction of $\gamma \delta 17 \mathrm{~T}$ cells by microbial colonization has also been associated with seemingly contrasting effects. Commensal-induced $\gamma \delta \mathrm{T}$ cells can mediate local protection against penetrating commensals (197), pathogenic bacteria or even yeast, as exemplified by the resistance displayed by $C$. mastidis colonized animals to ocular Candida albicans infection (24). In this model, induced $\gamma \delta \mathrm{T}$ cells were driving the production of antimicrobial peptides such as S100A8 and S100A9 and the recruitment of neutrophils through the production of IL17A. As IL-17A can elicit these responses in virtually all mucosal and epithelial surfaces, similar broad-spectrum anti-infectious immunity might occur in other $\gamma \delta \mathrm{T}$ cell rich tissues. In contrast to their protective effect against infection, microbiota-elicited 
$\gamma \delta 17 \mathrm{~T}$ cells may be beneficial (28) or harmful (29) in cancer. Other local detrimental effects attributed to microbiota-induced $\gamma \delta 17 \mathrm{~T}$ cells include the acceleration of nonalcoholic fatty liver disease by liver-resident $\gamma \delta 17 \mathrm{~T}$ cells (22) and the exacerbation of imiquimod-induced skin inflammation following C. accolens association (200).

Microbiota-elicited $\gamma \delta \mathrm{T}$ cells can also impact distal immune function. They express a plethora of homing receptors that allows them to navigate to distant tissues and impact health or disease. For example, $\gamma \delta \mathrm{T}$ cells are recruited to the ischemic penumbra after ischemic stroke in a CCR6-dependent manner (203). There, they contribute to exacerbate brain injury through the production of IL-17A and subsequent recruitment of neutrophils (203-205). In a recent study using a transient middle cerebral artery occlusion mouse model, the $\gamma \delta 17 \mathrm{~T}$ cells recruited to the ischemic brain originated from the small intestine and were dependent on specific commensal species for their maintenance (27). Alteration of the gut microbiota by antibiotic treatment led to a reduction in intestinal $\gamma \delta 17 \mathrm{~T}$ cells and diminished $\gamma \delta \mathrm{T}$ cell infiltration to the meninges, limiting injury. Thus, commensal-induced $\gamma \delta \mathrm{T}$ cells may have local and distal effects on pathological or physiological tissue processes.

It is now well established that the microbiota is a critical component of human health and disease. In addition to providing many enzymatic and metabolic pathways and colonization resistance to invading pathogens, commensals also participate in the development of and shaping of the immune system (206). Dysbiosis can be sensed by the immune system and has been associated with the development or exacerbation of many diseases in many organ systems. Given their preferential association with epithelial and mucosal tissues, it is not surprising that some $\gamma \delta \mathrm{T}$ cell populations are also influenced by the microbiota.

\section{INFLAMMATORY DISEASE AND MEMORY-LIKE $\gamma \delta 17 \mathrm{~T}$ CELL RESPONSE}

In addition to $\gamma \delta \mathrm{T}$ cell responses to the microbiota or after infection, $\gamma \delta$ T cells have also been implicated in innate responses in inflammatory disease. Inflammatory diseases with $\gamma \delta \mathrm{T}$ cell contributions include multiple sclerosis or EAE (72), psoriasis (135), collagen induced arthritis (73), ankylosing spondylitis (74), inflammatory bowel disease $(63,64)$, and uveitis $(75)$. One factor of inflammatory disease progression attributed to $\gamma \delta \mathrm{T}$ cells is IL17A production, a feature often associated with changes in the microbiota $(72,73,135)$. Inflammation-induced tissue damage may allow bacteria to bypass the epithelium leading to a positive feedback inflammatory loop. Interestingly, memory-like $\gamma \delta \mathrm{T}$ cell formation has been seen in inflammation of the skin (25, $26,51,207)$. IL-17A-producing $\mathrm{V} \gamma 2 \mathrm{~V} \delta 4^{+} \mathrm{T}$ cells initially derive from the neonatal thymus where they are instructed with tissue tropism. IMQ-induced psoriasis-like skin inflammation triggers a potent long-lived $\mathrm{V} \gamma 2 \mathrm{~V} \delta 4^{+} \mathrm{T}$ cell response (Figure 1) (25, 26). These $\mathrm{V} \gamma 2 \mathrm{~V} \delta 4^{+} \mathrm{T}$ cells were phenotypically memory-like with a $\mathrm{CD} 44^{\text {hi }} \mathrm{CD} 62 \mathrm{~L}^{\text {lo }} \mathrm{CD} 27^{-}$expression pattern. $\mathrm{V} \gamma 2 \mathrm{~V} \delta 4^{+}$ $\mathrm{T}$ cells expanded after primary challenge and migrated from the draining lymph nodes to both the inflamed and uninflamed skin in a S1P1-dependent manner where they persisted. Migration of $\mathrm{V} \gamma 2 \mathrm{~V} \delta 4^{+} \mathrm{T}$ cells from the circulation to the skin may also be influenced by signals including cutaneous lymphocyte antigen (CLA) binding to P- and E-selectins, CD103 interactions with E-cadherin, and C-C chemokine receptor type 2 (CCR2), and CCR6. CCR2 appeared essential for $\gamma \delta 17 \mathrm{~T}$ cell recruitment to inflamed tissues in B16 melanomas and EAE while CCR6 appeared necessary for dermal $\gamma \delta 17 \mathrm{~T}$ cell residence (208). Subsequent IMQ administration on previously untreated skin induced an accelerated and robust re-expansion of skin resident $\mathrm{V} \gamma 2 \mathrm{~V} \delta 4^{+} \mathrm{T}$ cells that produced IL-17A/F and exacerbated disease $(25,26)$. IL-17 production and subsequent neutrophil recruitment for skin disease appeared be partially dependent on an NFKB-inducing kinase (207). Enhanced inflammation with subsequent exposure was also associated with the $\mathrm{V} \gamma 2 \mathrm{~V} \delta 4^{+}$ $\mathrm{T}$ cell recall response but independent of $\alpha \beta \mathrm{T}$ cells (26). These findings were also noted in an acute contact dermatitis model using dinitrofluorobenzene where a similar memory $\mathrm{V} \gamma 2^{+}$ $\gamma \delta 17 \mathrm{~T}$ cell population appeared predominately tissue-resident in classical parabiosis experiments (51). Together, these studies suggest that $\gamma \delta$ T cells can modulate inflammatory diseases of the skin by forming long-lived tissue resident memory populations that exacerbate disease through the production of IL-17 family cytokines. While these studies suggest the establishment of longlived memory T cells, whether this response is driven by a specific antigenic responsiveness or is broadly reactive is unclear.

\section{INFECTION-INDUCED ADAPTIVE $\gamma \delta$ T CELLS: LONG-TERM PLAYERS IN MUCOSAL IMMUNITY}

Anamnestic immunity was thought to be mediated solely by conventional $\alpha \beta$ T cells and B cells. The recent identification of several innate and unconventional memory responses challenged this belief and has reshaped our view of immunological memory. $\gamma \delta \mathrm{T}$ cells bridge innate and adaptive immunity in many contexts by rapidly responding to stresses such as infections and promoting conventional adaptive immunity. For that reason, most mouse studies focused on $\gamma \delta \mathrm{T}$ cell responses in the first few hours to days after pathogen exposure or inflammatory insult. However, mounting evidence in humans, non-human primates and mice demonstrated that $\gamma \delta \mathrm{T}$ cells can mount adaptive-like responses. One of the most studied pathogens in that context is CMV. Indeed, the involvement of $\gamma \delta \mathrm{T}$ cells in the protective response to CMV infection was first suggested in kidney transplant patients whose $\gamma \delta \mathrm{T}$ cells underwent a massive and long-lasting expansion in the blood (34, 209, 210). $\gamma \delta \mathrm{T}$ cell expansion to $\mathrm{CMV}$ was also observed in the context of immunosuppression or immunodeficiency (35, $36,126,211-215)$, neonatal infection (216) and in otherwise healthy individuals $(35,125)$. Analysis of the repertoire of $\mathrm{CMV}$-selected $\gamma \delta \mathrm{T}$ cells revealed an oligoclonal and in some individuals even monoclonal population $(34,35,125)$, which, surprisingly, did not involve circulating $\mathrm{V} \gamma 9 \mathrm{~V} \delta 2^{+} \mathrm{T}$ cells but tissue tropic $\mathrm{V} \delta 2^{-} \gamma \delta \mathrm{T}$ cells. Expanded cells displayed a $\mathrm{T}_{\mathrm{EMRA}}$ 


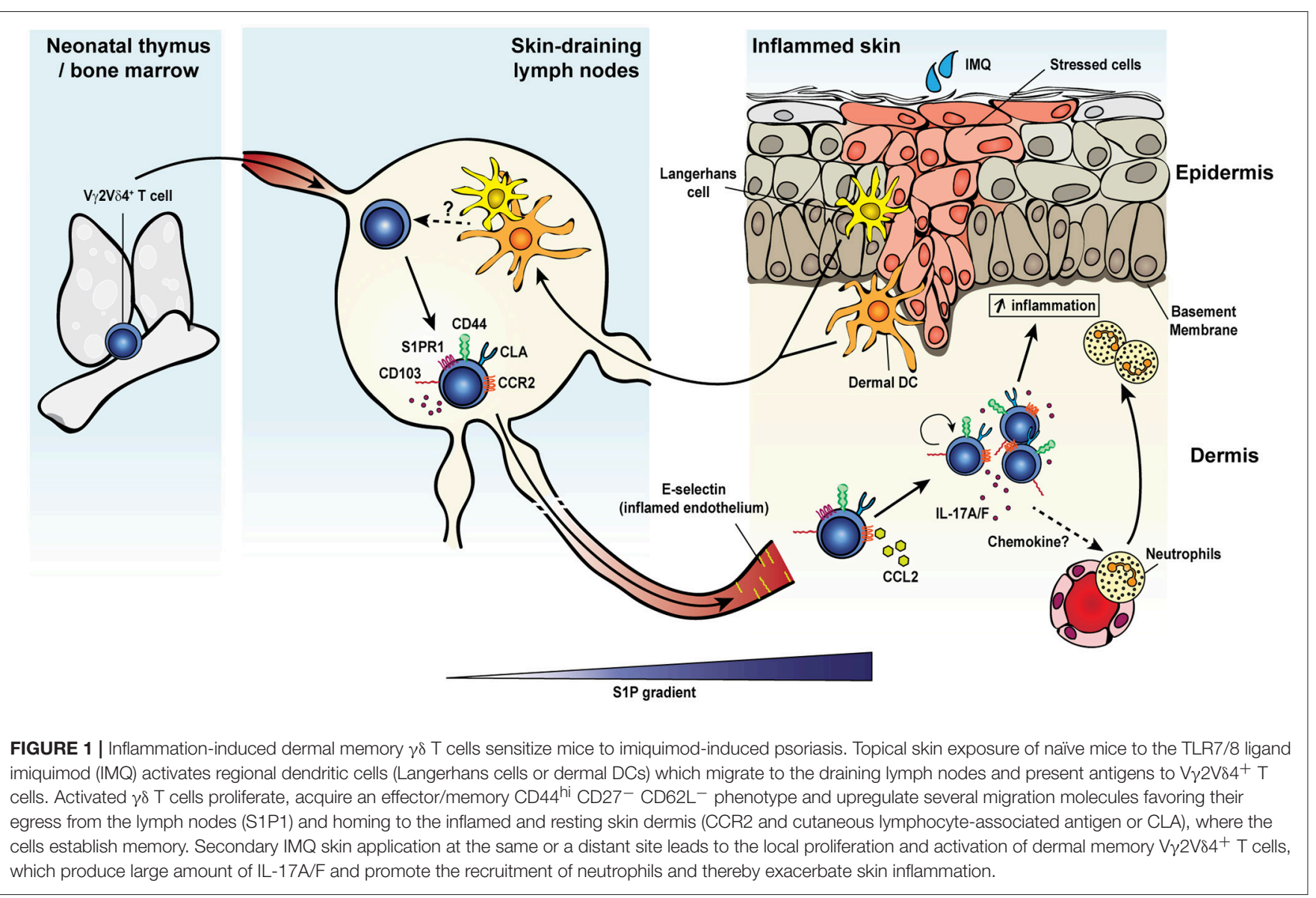

phenotype, similar to $\mathrm{CMV}$-specific $\mathrm{CD} 8^{+} \mathrm{T}$ cells (127), and only responded to CMV infection $(34,128)$. Importantly, the expansion of $\mathrm{V} \delta 2^{-} \gamma \delta \mathrm{T}$ cells correlated with the resolution of the acute infection in humans (210) and adoptive transfer of murine CMV-expanded $\gamma \delta \mathrm{T}$ cells conferred full protection to susceptible immunodeficient mice $(217,218)$. Thus, CMVelicited $\gamma \delta \mathrm{T}$ cells display many features classically attributed to conventional memory $\mathrm{T}$ cells. Another long-lived $\gamma \delta \mathrm{T}$ cell response to virus has been reported in the context of vaccinia virus immunization in humans (38) and rhesus macaques (39). Interestingly, vaccinia virus immunized macaques were protected against monkeypox virus challenge infection and this was associated with the expansion of circulating and pulmonary $\mathrm{V} \gamma 9 \mathrm{~V} \delta 2^{+} \mathrm{T}$ cells. Long-lasting adaptive-like $\gamma \delta \mathrm{T}$ responses were also reported in the circulation of individuals infected with the protozoan Plasmodium falciparum (P. falciparum) (40-43) and the circulation and peripheral tissues of animals infected with Plasmodium chabaudi (44). Interestingly, $\gamma \delta \mathrm{T}$ cell distribution to parasite-targeted tissues raises the possibility that these cells might provide unique functions to control parasite replication during the blood and liver stages. Collectively, these studies provide compelling evidence of adaptive $\gamma \delta \mathrm{T}$ cell responses triggered by unrelated pathogens in humans, non-human primates and rodents. However, the chronic or latent nature of the infections and their associated antigen and inflammation in conjunction with some inherent challenges associated with human studies has hindered conclusive demonstrations of the memory potential and long-term tissue residency of these populations.

\section{Infection-Induced bona fide Memory $\gamma \delta \mathrm{T}$ cell Responses}

Adaptive $\gamma \delta \mathrm{T}$ cells survey exposed mucosal and epithelial barriers where they may participate in pathogen clearance or control and have tissue-adapted functions. $\gamma \delta \mathrm{T}$ cells are one of the first immune responders in many bacterial infections, where they act concurrently with cells of the innate immune system. However, this innate $\gamma \delta \mathrm{T}$ cell response does not preclude the establishment of a subsequent localized memory $\gamma \delta \mathrm{T}$ cell response. A mouse model of peritonitis induced by repeated intraperitoneal exposure to Staphylococcus aureus (S. aureus), induced a rapid $\mathrm{V} \gamma 1.1^{+}$and $\mathrm{V} \gamma 2^{+} \gamma \delta 17 \mathrm{~T}$ cell response in the peritoneum and the draining mediastinal lymph nodes a few hours after exposure (49). After this early polyclonal innate response, a long-lived predominantly IL-17A-producing $\mathrm{V} \gamma 4^{+} \mathrm{T}$ cell population emerged in both tissues. Surprisingly, secondary challenge with $S$. aureus of previously exposed but pathogen-free mice induced a conventional memory response of $\mathrm{V} \gamma 4^{+} \mathrm{T}$ cells. Recalled $\mathrm{V} \gamma 4^{+} \mathrm{T}$ cells underwent secondary expansion, displayed an activated $\mathrm{CD} 44^{\mathrm{hi}} \mathrm{CD} 27^{-}$phenotype, 
and produced elevated levels of IL-17A. Adoptive transfer of purified $S$. aureus-elicited $\mathrm{V} \gamma 4^{+} \mathrm{T}$ cells was sufficient to protect naïve recipients against peritonitis and bacterial dissemination to the liver and kidneys (49). In contrast to the fundamental role of IL-1 $\beta$ in the induction of IL-17A production by naive $\gamma \delta \mathrm{T}$ cells during primary $S$. aureus exposure, memory $\mathrm{V} \gamma 4^{+}$ $\mathrm{T}$ cells were IL- $1 \beta$-independent suggesting that memory $\gamma \delta \mathrm{T}$ cells have an altered ability to respond to unique environmental cues to provide effector functions. Localized $S$. aureus infection of the skin in $I l 1 b^{-/-}$mice resulted in poor bacterial control during primary infection but protection against reinfection, revealing the potential presence of an additional memory $\gamma \delta \mathrm{T}$ cell subset. Indeed, intradermal infection induced the selective expansion of skin resident $\mathrm{V} \gamma 4 \mathrm{~V} \delta 1^{+}$and $\mathrm{V} \gamma 3 \mathrm{~V} \delta 1^{+} \mathrm{T}$ cell clones with conserved CDR $3 \delta$ and CDR3 $\gamma$ motifs that were maintained during the convalescent phase and present after secondary infection of WT and $I l 1 b^{-/-}$mice (50). Protection during secondary infection was conferred by IFN $\gamma$ - and TNF $\alpha$ producing $\gamma \delta \mathrm{T}$ cells. Adoptive transfer of purified S. aureuselicited $\gamma \delta \mathrm{T}$ cells, but not $\mathrm{CD} 4^{+} \mathrm{T}$ cells, neutrophils or serum from convalescent mice, was associated with bacterial clearance. Thus, different memory $\gamma \delta \mathrm{T}$ cell responses can be induced by the same pathogen and local memory $\gamma \delta \mathrm{T}$ cell populations may be tissue adapted to provide distinct protective mechanisms.

In addition to the memory responses involving $\mathrm{V} \gamma 4^{+} \mathrm{T}$ cells, a long-lasting protective response of ${\mathrm{V} \gamma 2^{+}}^{+} \mathrm{T}$ cells was observed after pulmonary Bordetella pertussis (B. pertussis) infection (Figure 2) (48). After an early innate response dominated by IL17A-producing $\mathrm{V} \gamma 1.1^{-} \mathrm{V} \gamma 2^{-} \gamma \delta \mathrm{T}$ cells, effector memory CD44 ${ }^{+}$ $\mathrm{CD} 27^{-} \mathrm{V} \gamma 2^{+} \mathrm{T}$ cells started accumulating from day 14 and were maintained long-term in the lungs. The later emergence of $\mathrm{V}_{\gamma} 2^{+}$ $\mathrm{T}$ cells coincided with the expansion of $\mathrm{T}_{\mathrm{RM}}$ precursors and $\mathrm{T}_{\mathrm{EM}}$-like CD4 ${ }^{+} \mathrm{T}$ cells in the lungs (219). Expanded pulmonary $\mathrm{V} \gamma 2^{+} \mathrm{T}$ cells share several features with $B$. pertussis-specific memory CD4 T cells: (i) they reside in the lungs for a prolonged period of time after bacterial clearance and rapidly and locally proliferated in response to secondary pulmonary challenge, (ii) a considerable fraction expresses the $\mathrm{T}_{\mathrm{RM}}$ marker CD69 and some also co-express CD103, (iii) they have a strict reactivity to $B$. pertussis, (iv) they are biased toward IL-17A production, and (v) they contribute to enhanced bacterial clearance after challenge $(48,219)$. Thus, $B$. pertussis-elicited memory $\gamma \delta \mathrm{T}$ cells closely resemble conventional $\mathrm{T}_{\mathrm{RM}}$ cells. In contrast to the reported displacement of skin DETC by virus-specific CD8 ${ }^{+} \mathrm{T}_{\mathrm{RM}}$ (168), $\mathrm{CD}^{+}{ }^{+} \mathrm{T}_{\mathrm{RM}}$ and memory $\gamma \delta \mathrm{T}$ cells were able to coexist in the lungs of infected mice and both subsets expanded after infection and participated in conferring protection, suggesting that they may reside in distinct niches within the tissue or do not compete for space or survival factors.

Microorganisms producing PAgs are potent activators of human and non-human primate $\mathrm{V} \gamma 9 \mathrm{~V} \delta 2^{+} \mathrm{T}$ cells. Mycobacteria, including Mycobacterium bovis BCG strain and Mycobacterium tuberculosis (M. tuberculosis), produce HMBPP (220-222), the most potent $\mathrm{V} \gamma 9 \mathrm{~V} \delta 2^{+} \mathrm{T}$ cell activator. Correspondingly, intravenous (i.v.) BCG vaccination of macaques triggered a drastic expansion of these circulating cells in the blood, but also in the lungs and the intestines (45). Pulmonary $M$. tuberculosis infection led to a similar expansion of mucosal but not circulating $\mathrm{V} \gamma 9 \mathrm{~V} \delta 2^{+} \mathrm{T}$ cells (47), demonstrating tissue-adapted responses by adaptive $\gamma \delta \mathrm{T}$ cells that may be

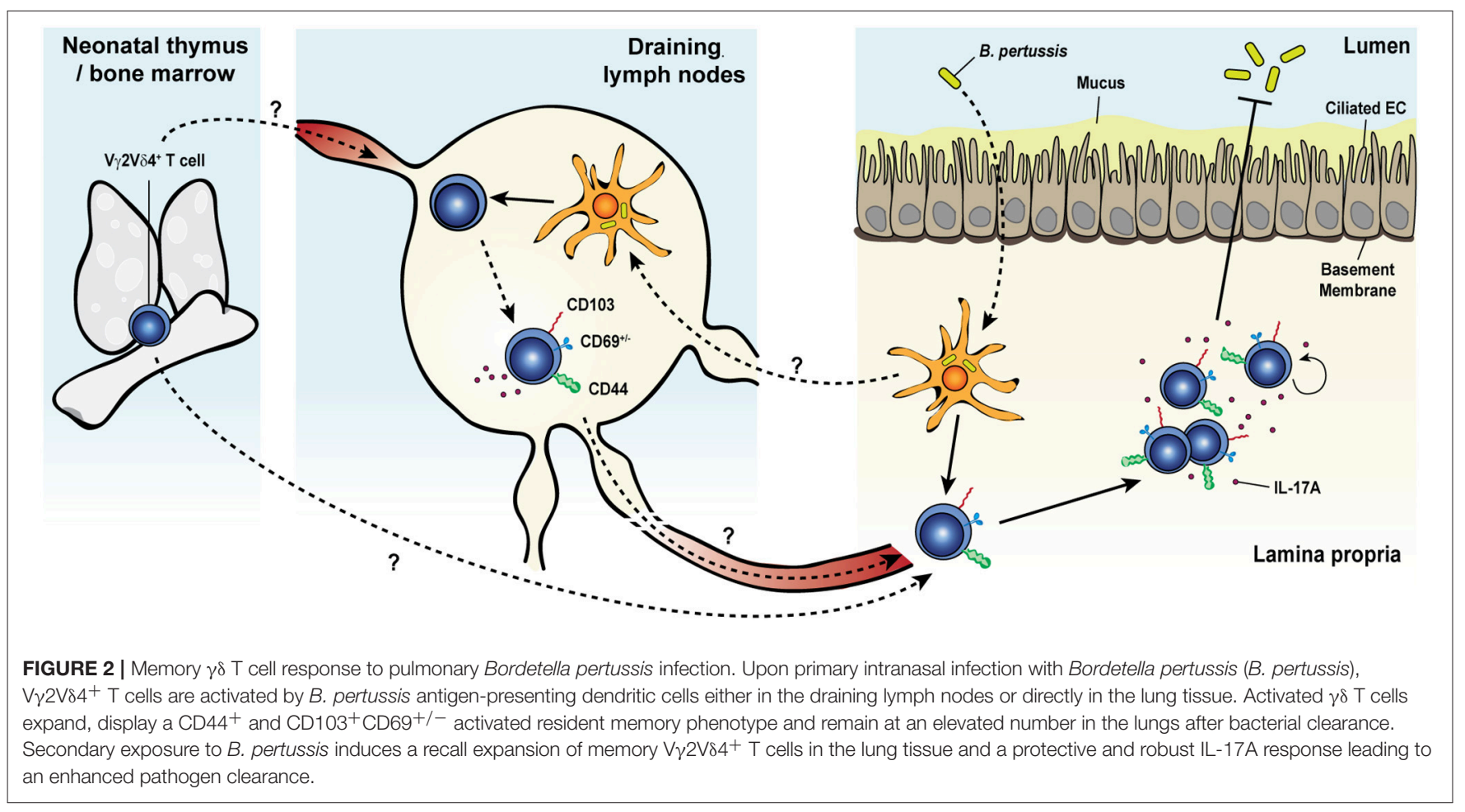


predicated on immunization route. BCG challenge of vaccinated monkeys induced a more rapid and robust clonal expansion of $\mathrm{V} \gamma 9 \mathrm{~V} \delta 2^{+} \mathrm{T}$ cells but no other $\gamma \delta \mathrm{T}$ cell subsets. Thus, $\mathrm{V} \gamma 9 \mathrm{~V} \delta 2^{+} \mathrm{T}$ cells are capable of forming long-lived clonallyexpanded memory responses (45). Interestingly, direct contact with antigen presenting cells was required for the recall-like expansion of $\mathrm{V} \gamma 9 \mathrm{~V} \delta 2^{+} \mathrm{T}$ cells (46). The recall response of $\mathrm{V} \gamma 9 \mathrm{~V} \delta 2^{+} \mathrm{T}$ cells in BCG immunized macaques was associated with enhanced clearance of challenge infection and protection against fatal tuberculosis (45). In line with these findings, $\mathrm{V} \gamma 9 \mathrm{~V} \delta 2^{+} \mathrm{T}$ cells induced in BCG vaccinated volunteers that were previously unexposed to any mycobacteria showed an enhanced responsiveness to $M$. tuberculosis ex vivo (223), suggesting that BCG vaccination also primes $\gamma \delta \mathrm{T}$ cells to respond to $M$. tuberculosis in humans. Although human and monkey $\mathrm{V} \gamma 9 \mathrm{~V} \delta 2^{+} \mathrm{T}$ cells share many features, including a memorylike response to mycobacteria, it remains to be established whether human $\gamma \delta \mathrm{T}$ cells, like their non-human primate counterparts, are maintained in peripheral tissues following BCG immunization to confer some protection against $M$. tuberculosis infection.

\section{Multifunctional Memory $\gamma \delta$ T Cells to $L$. monocytogenes}

L. monocytogenes is known to be a potent inducer of $\gamma \delta \mathrm{T}$ cell responses. In humans, expansion of $\mathrm{V} \gamma 9 \mathrm{~V} \delta 2^{+} \mathrm{T}$ cells has been detected in the blood of pregnant women, newborns, infants and the elderly early after L. monocytogenes exposure (224, 225). These $\gamma \delta \mathrm{T}$ cells displayed an activated (HLA$\left.\mathrm{DR}^{+}\right)$and memory $\left(\mathrm{CD} 45 \mathrm{RO}^{+}\right)$phenotype. Consistent with a predetermined innate response, stimulation of PBMC from healthy donors with heat-killed L. monocytogenes (225), listeria lysate or culture supernatant (226) led to rapid proliferation of $\mathrm{V} \gamma 9 \mathrm{~V} \delta 2^{+} \mathrm{T}$ cells.

A similar mobilization of circulating $\gamma \delta \mathrm{T}$ cells during L. monocytogenes infection has also been reported in rhesus macaques. In a model of disseminated L. monocytogenes infection, $\mathrm{V} \gamma 9 \mathrm{~V} \delta 2^{+} \mathrm{T}$ cells increased in the blood of rhesus macaques infected with an attenuated $L$. monocytogenes strain through an intramuscular, and to a lesser extent i.v. route (59). These cells were also elevated in bronchoalveolar lavages and rectal biopsies suggesting that they actively traffic to and seed mucosal tissues during infection. More interestingly, $L$. monocytogenes challenge of immunized animals led to a rapid and robust re-expansion of $\mathrm{V} \gamma 9 \mathrm{~V} \delta 2^{+} \mathrm{T}$ cells that correlated with the resolution of infection (59). One peculiar feature of $L$. monocytogenes is its ability to use both the classical mevalonate and the alternative MEP pathways for isoprenoid synthesis (227). Both primary and recall-like responses of $\mathrm{V} \gamma 9 \mathrm{~V} \delta 2^{+} \mathrm{T}$ cells have been shown to rely on the bacteria's ability to co-produce mevalonate-derived isopentenyl pyrophosphate and MEPderived HMBPP, the latter being much more efficient at inducing primary and secondary expansion of primate $\mathrm{V} \gamma 9 \mathrm{~V} \delta 2^{+} \mathrm{T}$ cells and promoting their differentiation into $\mathrm{CD} 27^{+} \mathrm{CD}^{+} 5 \mathrm{RA}^{-}$ $\mathrm{CD}^{-} 8^{-}$memory cells (60). L. monocytogenes-elicited $\gamma \delta \mathrm{T}$ cells displayed various effector functions after secondary challenge, including production of IFN $\gamma$, IL-4, IL-17A, and $\mathrm{TNF} \alpha$ (59). Surprisingly, a substantial portion of these cells were multifunctional and simultaneously produced IFN $\gamma$ and IL-17A, IFN $\gamma$ and IL-4, or TNF $\alpha$ and perforin in response to HMBPP $(59,60)$. Expanded $\mathrm{V} \gamma 9 \mathrm{~V} \delta 2^{+} \mathrm{T}$ cells were also potent bactericidal effectors capable of efficiently lysing L. monocytogenes-infected DC and restraining intracellular bacterial growth in macrophages ex vivo. Thus, L. monocytogenes infection elicits a multifunctional circulating $\gamma \delta \mathrm{T}$ cell response in non-human primates. Because this response is accompanied by the colonization of epithelial tissues, infection-elicited mucosal $\gamma \delta \mathrm{T}$ cells may also have distinct effector functions that provide tissue-adapted responses.

A large body of evidence has convincingly demonstrated the involvement of $\gamma \delta \mathrm{T}$ cells in the early phase of the primary immune response to systemic L. monocytogenes infection of mice $(228-244)$ and rats $(245,246)$. More recently, our group reported a bona fide memory $\gamma \delta \mathrm{T}$ cell response in mice after food-borne infection with a mouse-adapted L. monocytogenes capable of intestinal epithelial cell invasion (Figure 3) $(62,134,247)$. Foodborne infection induced a long-lived $\mathrm{V} \gamma 4 \mathrm{~V} \delta 1^{+} \mathrm{T}$ cell population in the gut draining mesenteric lymph node (MLN) with a CD $44^{\text {hi }}$ CD27- ${ }^{-}$phenotype (62). By 7 days after infection, these cells were mobilized into the blood, up-regulated the gut-homing integrin $\alpha_{4} \beta_{7}$ and trafficked to the intestinal lamina propria similarly to conventional L. monocytogenes-specific CD8 ${ }^{+}(248)$ and $\mathrm{CD}^{+}{ }^{+}$(249) $\alpha \beta \mathrm{T}$ cells. Like L. monocytogenes-induced $\mathrm{CD}^{+}$and $\mathrm{CD}^{+} \alpha \beta \mathrm{T}_{\mathrm{RM}}$ cells, L. monocytogenes-elicited $\gamma \delta$ $\mathrm{T}$ cells established residency in MLN and intestinal lamina propria where they were maintained long term in the absence of further antigenic stimulation $(62,134)$. The generation of this $\gamma \delta \mathrm{T}$ cell subset was restricted to tissues associated with the gastrointestinal system and was induced by foodborne (62) but not i.v. infection $(232,233)$. L. monocytogeneselicited $\gamma \delta$ T cells demonstrated enhanced anamnestic response upon L. monocytogenes challenge infection and were fully competent for immunologic boosting upon tertiary exposure (62). Although L. monocytogenes-elicited $\gamma \delta \mathrm{T}$ cells appeared to share a similar anatomical niche as L. monocytogenesspecific $\mathrm{CD}^{+}{ }^{+}$and $\mathrm{CD} 8^{+} \alpha \beta \mathrm{T}$ cells $(248,249)$, all populations expanded robustly after infection and were maintained without any apparent competition for limiting resources or anatomic space.

Memory $\gamma \delta \mathrm{T}$ cells cooperated with $\alpha \beta \mathrm{T}$ cells to confer optimal protection in the MLN and the small intestine during food-borne L. monocytogenes challenge infection. Indeed, only the concomitant antibody-mediated depletion of $\alpha \beta \mathrm{T}$ cells (both $\mathrm{CD}^{+}$and $\mathrm{CD}^{+}$) and forced internalization of the $\gamma \delta$ TCR resulted in the complete loss of protection afforded to immunized mice, whereas the sole removal of $\alpha \beta \mathrm{T}$ cells only partially impaired L. monocytogenes control (62). One striking feature of L. monocytogenes-elicited $\gamma \delta \mathrm{T}$ cells was their ability to produce IFN $\gamma$ and IL-17A during each stage of the immune response. Moreover, subsets within the CD $44^{\text {hi }}$ $\mathrm{CD}^{2} 7^{-} \gamma \delta \mathrm{T}$ cell population co-produced both cytokines during the primary and secondary responses (62), reminiscent of the multifunctional response described in rhesus macaques after 


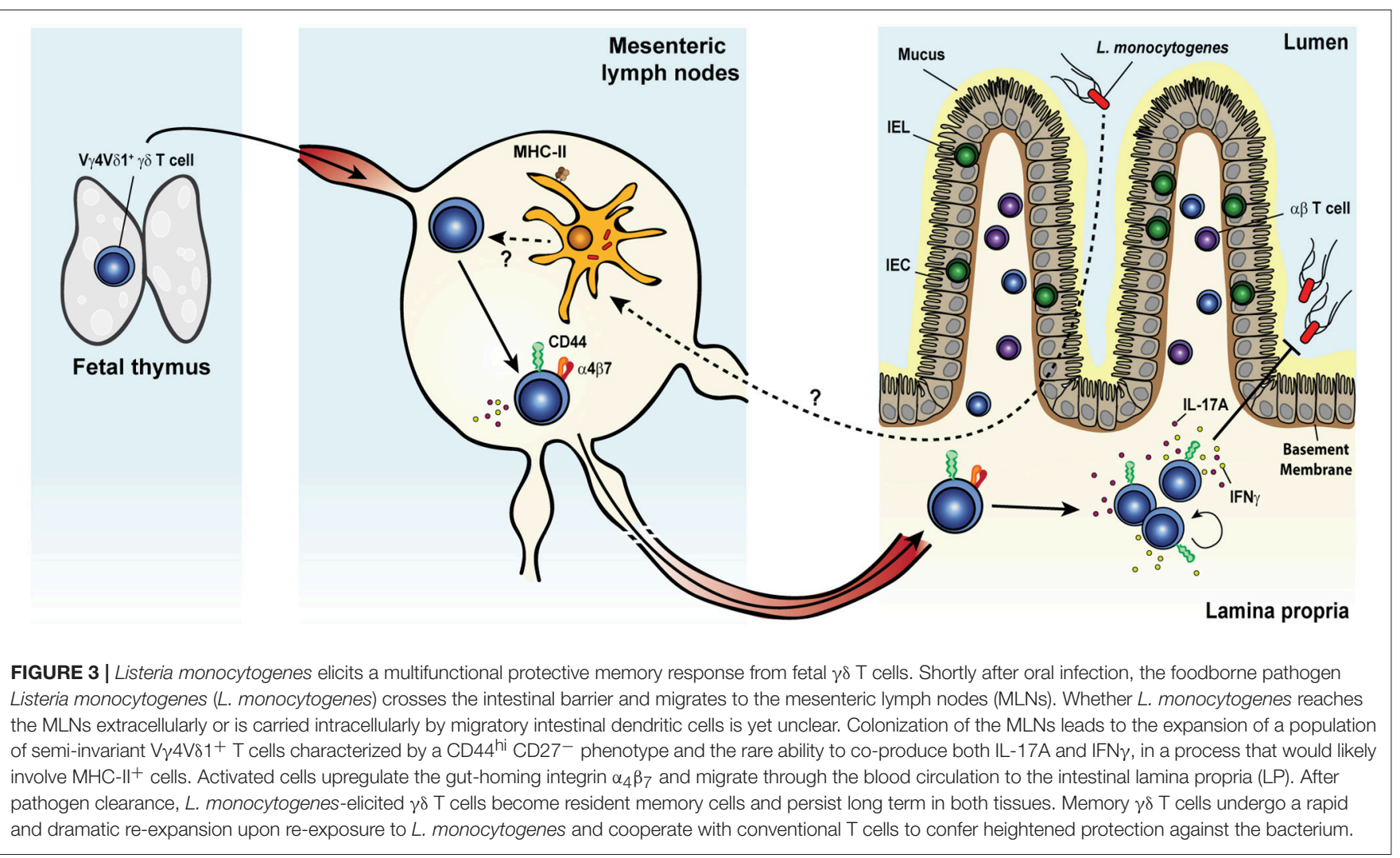

secondary challenge (59). During the recall response, the majority of IL-17A was derived from reactivated memory $\gamma \delta \mathrm{T}$ cells in the MLN. This production of IL-17A was a critical component of anti-listerial immunity as it mediated the formation of $L$. monocytogenes-containing immune cell clusters composed of memory $\gamma \delta \mathrm{T}$ cells and IL-17RA ${ }^{+}$inflammatory monocytes and neutrophils (134).

Collectively, these studies demonstrate that systemic and food-borne L. monocytogenes infection generates long-lived multifunctional memory $\gamma \delta \mathrm{T}$ cells in rhesus macaques and mice, respectively. Thus, a population of pathogen-elicited $\gamma \delta \mathrm{T}$ cells appears to behave very similarly between mice and primates, and this may suggest a conserved biology among mucosal $\gamma \delta$ $\mathrm{T}$ cells. These studies also highlight the important influence of infection route and models that mimic natural infection on understanding the $\gamma \delta \mathrm{T}$ cell response. Interestingly, amongst the memory and memory-like responses described to date, $L$. monocytogenes is the only agent known to induce multifunctional $\gamma \delta \mathrm{T}$ cells in two distinct species. Although $\gamma \delta 17 \mathrm{~T}$ cells are known to have a permissive chromatin state for IFN $\gamma$ expression (102), other memory $\gamma \delta \mathrm{T}$ cell populations reported in mice only produce IL-17A $(25,26,48,49)$. Conversely, only IFN $\gamma$ was shown to be produced by virus-activated memory-like $\mathrm{V} \gamma 9 \mathrm{~V} \delta 2^{+}$ $\mathrm{T}$ cells (39). miR-146a has recently been shown to negatively regulate IFN $\gamma$ production by murine $\gamma \delta 17 \mathrm{~T}$ cells, including during oral L. monocytogenes infection (61). Elucidating the mechanisms by which $L$. monocytogenes partially breaks miR146a-mediated inhibition of IFN $\gamma$ production by $\gamma \delta 17 \mathrm{~T}$ cells and understanding why other pathogens do not would provide important clues about the fine regulation of $\gamma \delta 17 \mathrm{~T}$ cell functions and might open new avenues for the manipulation of these cells.

\section{ANTI-TUMOR MEMORY $\gamma \delta$ T CELLS IN CANCER}

A substantial body of research has focused on the beneficial nature of $\gamma \delta \mathrm{T}$ cells in anti-cancer immunity and their potential as a targetable therapeutic since a landmark study demonstrated that $\gamma \delta \mathrm{T}$ cells in the epithelial compartment play a substantial role in prevention of cutaneous carcinogenesis (57). Indeed, the presence of an intra-tumoral $\gamma \delta \mathrm{T}$ cell gene signature was associated with the single most favorable prognostic indicator of patient outcome for a wide range of cancers (250). $\gamma \delta \mathrm{T}$ cells can have a wide range of effects ranging from reshaping the tumor microenvironment $(251,252)$, being integral in promoting a diverse cancer protective IgE repertoire through NKG2D stress surveillance (166), or IFN $\gamma$ production (52). Substantial effort has focused on resolving the anti-tumor activity of $\mathrm{V} \gamma 9 \mathrm{~V} \delta 2^{+} \mathrm{T}$ cells, the predominant $\gamma \delta \mathrm{T}$ cell population in human PBMC, in multiple cancers (253-257). Tissue resident $\mathrm{V} \delta 2^{-} \gamma \delta \mathrm{T}$ cells may also substantially contribute to anti-tumor immunity. $\mathrm{V} \delta 2^{-} \gamma \delta$ $\mathrm{T}$ cells typically predominate over $\mathrm{V} \delta 2^{+} \mathrm{T}$ cells within tumors $(52,65)$ as well as in tissues from healthy individuals $(120)$. This $\mathrm{V} \delta 2^{-} \gamma \delta \mathrm{T}$ cell population is principally composed of $\mathrm{V} \delta 1^{+} \mathrm{T}$ 
cells but also contain a significant population of $\mathrm{V} \delta 3^{+} \mathrm{T}$ cells. Due to $\mathrm{V} \delta 2^{-} \gamma \delta \mathrm{T}$ cell prevalence in tumor microenvironment, it is likely that this subset also substantially contributes to antitumor activity.

$\mathrm{V} \gamma 9 \mathrm{~V} \delta 2^{+} \mathrm{T}$ cells were previously delineated based on expression of CD45RA and CD27 as naive (CD45RA ${ }^{+} \mathrm{CD}_{2}{ }^{+}$) cells or effector and memory $\mathrm{T}_{\mathrm{CM}}\left(\mathrm{CD} 45 \mathrm{RA}^{-} \mathrm{CD} 27^{+}\right), \mathrm{T}_{\mathrm{EM}}$

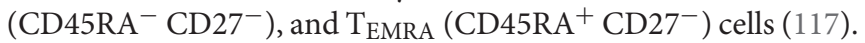
While naive $\mathrm{T}$ cells and $\mathrm{T}_{\mathrm{CM}}$ cells primarily reside in secondary lymphoid tissues, $\mathrm{T}_{\mathrm{EM}}$ and $\mathrm{T}_{\mathrm{EMRA}}$ migrate to inflammatory sites to perform effector functions. These latter populations have been investigated in multiple cancers including squamous cell carcinoma (SCC) (52), CRC (65), neuroblastoma (71), and melanoma (53) due to their proliferative capacity and tendency to migrate toward inflammatory sites. Substantial effort has also sought to leverage the anti-tumor properties of $\mathrm{V} \gamma 9 \mathrm{~V} \delta 2^{+} \mathrm{T}$ cells using approaches like in vitro expansion of patient-derived $\gamma \delta \mathrm{T}$ cells and chimeric antigen receptor $\mathrm{T}$ cells for potential adoptive immunotherapies $(258,259)$. V $\gamma 9 \mathrm{~V} \delta 2^{+} \mathrm{T}$ cells can be selectively activated through PAgs or amino bisphosphonates such as zoledronic acid (zoledronate) in combination with various growth factors, cytokines, or costimulatory molecules (260). While various adoptive transfer methods have been primarily explored in a number of pre-clinical studies (261-267), to date, clinically favorable outcomes appear limited to prostate cancer (137). However, challenges remain in the rapid and robust generation of the large numbers of cells that would be necessary for successful adoptive immunotherapies (268). Zoledronate also has various indirect effects on $\gamma \delta \mathrm{T}$ cells by independently impacting the tumor microenvironment $(251,269,270)$, which can provide a pro-tumor or anti-tumor outcome $(271,272)$. As such, it will be important to assess the contribution of $\gamma \delta \mathrm{T}$ cells and the impact of any therapies in individual tumor types.

A protective role of tissue resident $\gamma \delta 17 \mathrm{~T}$ cells has been readily described in the context of infectious disease, but they have also been implicated in exacerbating chronic inflammatory diseases like psoriasis. Chronic inflammatory disease is a risk factor and clinical precursor to a number of cancers including pancreatic cancer (273), skin cancer (274) and CRC (275). A growing body of literature has also demonstrated a $\gamma \delta \mathrm{T}$ cell response that promotes tumor growth. This pro-tumor outcome of some $\gamma \delta$ T cell responses appears predominately a consequence of IL-17A production that is often associated with the upregulation of proliferation pathways in cancerous lesions (276) (Figure 4). These apparent anti- and pro-tumor discrepancies are likely due to the dichotomous functional outcomes associated with type-1 or type-17 $\gamma \delta \mathrm{T}$ cell responses. A pro-tumor role of IL-17A-producing $\gamma \delta \mathrm{T}$ cells is evident in a number of cancers such as SCC (52), CRC (29), and metastatic breast cancer (70). In human SCC, tumor infiltration of IL-17A-producing $\mathrm{V} \delta 1^{+}$ and $\mathrm{V} \delta 2^{+} \mathrm{T}$ cells was associated with a negative prognosis, in contrast to a more favorable outcome associated with tumorinfiltrating IFN $\gamma$-producing $\gamma \delta \mathrm{T}$ cells (52). Similar results were seen in human CRC where a predominately $\mathrm{V} \delta 1^{+}$IL-17Aproducing $\gamma \delta \mathrm{T}$ cell population positively correlated with a more advanced tumor stage. This correlation was attributed

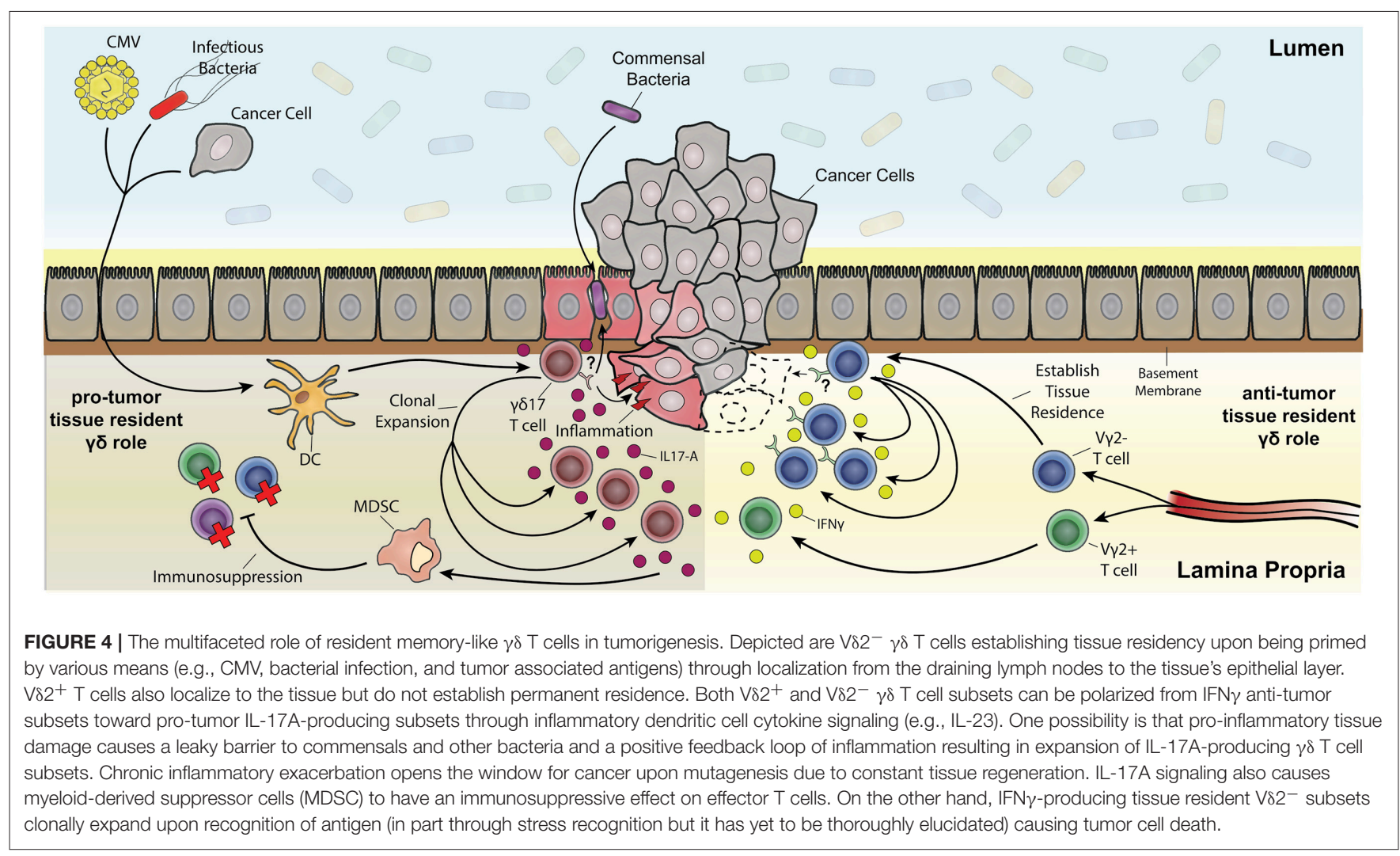


to an inflammatory DC - $\gamma \delta 17 \mathrm{~T}$ cell - MDSC regulatory axis (29). Interestingly, tissue resident memory $\mathrm{V} \gamma 2^{+} \mathrm{T}$ cells were also seen in a metastatic mouse model of breast cancer. These $\mathrm{V} \gamma 2^{+} \mathrm{T}$ cells produced IL-17A and G-CSF, which promoted the establishment of immunosuppressive intratumoral MDSC (70). Collectively, these studies implicate tissue resident $\mathrm{V} \delta 1^{+}$ and $\mathrm{V} \gamma 2^{+} \mathrm{T}$ cells as tumor growth promoting through IL17A-mediated MDSC recruitment and immunosuppression in cancer. More importantly, these findings segregate deleterious $\gamma \delta \mathrm{T}$ cell responses from those which may have a beneficial outcome.

On the other hand, $\mathrm{V} \delta 2^{-} \gamma \delta \mathrm{T}$ cells are not limited to protumor effects and effort has been invested into their therapeutic benefits. Intrahepatic $\mathrm{V} \delta 1^{+}$and $\mathrm{V} \delta 3^{+} \mathrm{T}$ cells express a CD45RA ${ }^{+}$ $\mathrm{CD}^{-} 7^{-}$and $\mathrm{CD} 45 \mathrm{RA}^{-} \mathrm{CD}^{-} 7^{-}$phenotype that is nearly absent from the blood. Intrahepatic CD45RA ${ }^{-} \mathrm{CD} 27^{-} \mathrm{V} \delta 1^{+}$and $\mathrm{V} \delta 3^{+}$ $\mathrm{T}$ cells were competent producers of IFN $\gamma$ and TNF $\alpha$ and also expressed receptors for early activation and tissue retention, such as CD69, that have also been noted in both liver resident NK and $\mathrm{CD}^{+} \alpha \beta \mathrm{T}$ cell populations $(120,277)$. CMV infection has notably been one of the drivers of hepatic $\mathrm{V} \delta 2^{-} \gamma \delta \mathrm{T}$ cell expansion and memory formation, and these factors appear to have a protective effect against tumor formation. CMVseropositive patients (infected pre- or post-transplantation) have a reduced risk of skin cancer development and leukemia relapse after kidney or bone marrow transplant, respectively $(36,37)$. $\mathrm{V} \delta 2^{-} \gamma \delta \mathrm{T}$ cells from CMV-infected kidney transplant patients were capable of killing HT29 colon cancer cells in vitro (128) and CMV-induced $\mathrm{V} \delta 2^{-} \gamma \delta \mathrm{T}$ cells had anti-tumor activity against primary and metastatic tumors in a HT29 xenograft mouse model $(278,279)$. The characterization of the antigenic specificity of one highly expanded $\gamma \delta \mathrm{T}$ cell clone from a CMVseropositive transplant patient revealed that its recognition of stressed (infected or transformed) cells was mediated by the direct binding of the TCR to EPCR, independently of its cargo (33). Similarly, Annexin A2 is upregulated at the surface of stressed cells and can activate another $\mathrm{V} \delta 2^{-} \gamma \delta \mathrm{T}$ cell clone (123). However, regardless of which epitope is being recognized, TCR sequencing of intrahepatic $V \delta 2^{-} \gamma \delta \mathrm{T}$ cell populations has revealed that $\mathrm{CMV}$ infection can induce expansion, memory phenotypes, and tumor reactivity in a clonally expansive manner (120). Overall, these studies suggest that $\mathrm{V} \delta 2^{-} \gamma \delta$ $\mathrm{T}$ cells form $\mathrm{T}_{\mathrm{RM}}$ cell populations that can clonally expand and cross-react with tumor epitopes to provide anti-tumor immunity.

Knowledge of resident $\gamma \delta \mathrm{T}$ cell biology is integral for future cancer therapies. Despite intra-tumoral $\gamma \delta \mathrm{T}$ cell gene signatures being regarded as a favorable prognostic, there is a delicate balance between becoming pro-tumor and anti-tumor $\gamma \delta \mathrm{T}$ cells (Figure 4). Pro-tumor populations are characterized by $\gamma \delta 17 \mathrm{~T}$ cells and their indirect immunosuppressive activity through MDSC (29). On the other hand, anti-tumor populations are characterized by IFN $\gamma$ producing $\gamma \delta \mathrm{T}$ cells (52). Notably, IgE response mediated by DETC stress surveillance can have anti-tumor effects (166) as well as potential autoimmune effects (280). A better understanding of how signals in tumor microenvironment shape and potentially polarize $\gamma \delta \mathrm{T}$ cell cytokine production and signal to other cells would be of great benefit.

\section{CONCLUDING REMARKS}

The roles of $\gamma \delta$ T cells in response to pathogens and commensals and in inflammatory disease and cancer have been an area of expanding interest over the last decade generating significant advances in knowledge. However, our basic understanding of $\gamma \delta \mathrm{T}$ cell biology is still largely incomplete and lags far behind our understanding of their $\alpha \beta \mathrm{T}$ cell counterparts, particularly in the area of anamnestic responses. $\gamma \delta \mathrm{T}$ cells are adapted to their tissue environment which in turn shapes the immune landscape of that environment. Like most cells of the immune system, $\gamma \delta \mathrm{T}$ cells can appear duplicitous under certain circumstances. On one hand, they can provide beneficial outcomes to the host by conferring anti-pathogen and antitumor immunity. On the other hand, they can lead to negative outcomes or exacerbated disease in some inflammatory disorders and cancers. Regardless of their impact, it is now clear that $\gamma \delta$ $\mathrm{T}$ cell responses encompass both innate inflammatory responses and more traditional adaptive memory responses that provide substantial opportunities for therapeutic targeting. Memory $\gamma \delta$ $\mathrm{T}$ cell responses may advance a new arm of rationale vaccine design that has broad implications for boosting anti-pathogen or anti-tumor immunity. Vaccines that elicit broadly reactive long-lived circulating or tissue-resident memory $\gamma \delta \mathrm{T}$ cells may provide protection against a wide range of cancers and infections. Similarly, innate inflammatory or adaptive effector responses may be targeted to enhanced therapeutic modalities with far ranging implications. In the context of a detrimental impact on human health, $\gamma \delta \mathrm{T}$ cell responses may be blunted or, in the context of cancer, diverted to a lineage that promotes tumor eradication. Thus, memory and tissue-resident $\gamma \delta \mathrm{T}$ cells represent a lineage of the adaptive immune system that necessitate greater understanding to facilitate the generation of novel therapeutics to promote human health and reduce disease.

\section{AUTHOR CONTRIBUTIONS}

CK wrote the first draft of the manuscript. THC wrote sections of the manuscript. All authors contributed to manuscript revision, read and approved the submitted version.

\section{FUNDING}

BS is supported by NIH grant (R01 AI076457, R21 AG058981, R21 AI137929), US DOD grant (CA171143), and funds provided by Stony Brook University. 


\section{REFERENCES}

1. Lee YK, Mazmanian SK. Has the microbiota played a critical role in the evolution of the adaptive immune system? Science (2010) 330:1768-73. doi: 10.1126/science.1195568

2. Ivanov, II, Atarashi K, Manel N, Brodie EL, Shima T, Karaoz U, et al. Induction of intestinal Th17 cells by segmented filamentous bacteria. Cell (2009) 139:485-98. doi: 10.1016/j.cell.2009.09.033

3. Naik S, Bouladoux N, Linehan JL, Han SJ, Harrison OJ, Wilhelm C, et al. Commensal-dendritic-cell interaction specifies a unique protective skin immune signature. Nature (2015) 520:104-8. doi: 10.1038/nature 14052

4. Naik S, Bouladoux N, Wilhelm C, Molloy MJ, Salcedo R, Kastenmuller W, et al. Compartmentalized control of skin immunity by resident commensals. Science (2012) 337:1115-9. doi: 10.1126/science.1225152

5. Wu HJ, Ivanov, II, Darce J, Hattori K, Shima T, Umesaki Y, et al. Gut-residing segmented filamentous bacteria drive autoimmune arthritis via $\mathrm{T}$ helper 17 cells. Immunity (2010) 32:815-27. doi: 10.1016/j.immuni.2010.06.001

6. Lee YK, Menezes JS, Umesaki Y, Mazmanian SK. Proinflammatory Tcell responses to gut microbiota promote experimental autoimmune encephalomyelitis. Proc Natl Acad Sci USA. (2011) 108 (Suppl 1):4615-22. doi: 10.1073/pnas.1000082107

7. Schenkel JM, Masopust D. Tissue-resident memory T cells. Immunity (2014) 41:886-97. doi: 10.1016/j.immuni.2014.12.007

8. Mueller SN, Mackay LK. Tissue-resident memory T cells: local specialists in immune defence. Nat Rev Immunol. (2016) 16:79-89. doi: 10.1038/nri.2015.3

9. Netea MG, Quintin J, van der Meer JW. Trained immunity: a memory for innate host defense. Cell Host Microbe (2011) 9:355-61. doi: 10.1016/j.chom.2011.04.006

10. Netea MG, Joosten LA, Latz E, Mills KH, Natoli G, Stunnenberg HG, et al. Trained immunity: A program of innate immune memory in health and disease. Science (2016) 352:aaf1098. doi: 10.1126/science.aaf1098

11. Cerwenka A, Lanier LL. Natural killer cell memory in infection, inflammation and cancer. Nat Rev Immunol. (2016) 16:112-23. doi: 10.1038/nri.2015.9

12. Peng H, Tian Z. Natural Killer Cell Memory: Progress and Implications. Front Immunol. (2017) 8:1143. doi: 10.3389/fimmu.2017.01143

13. Bonneville M, O’Brien RL, Born WK. Gammadelta T cell effector functions: a blend of innate programming and acquired plasticity. Nat Rev Immunol. (2010) 10:467-78. doi: 10.1038/nri2781

14. Chien YH, Meyer C, Bonneville M. gammadelta $\mathrm{T}$ cells: first line of defense and beyond. Annu Rev Immunol. (2014) 32:121-55. doi: 10.1146/annurev-immunol-032713-120216

15. Hayday AC. Gammadelta $\mathrm{T}$ cells and the lymphoid stress-surveillance response. Immunity (2009) 31:184-96. doi: 10.1016/j.immuni.2009. 08.006

16. Itohara S, Farr AG, Lafaille JJ, Bonneville M, Takagaki Y, Haas W, et al. Homing of a gamma delta thymocyte subset with homogeneous T-cell receptors to mucosal epithelia. Nature (1990) 343:754-7. doi: $10.1038 / 343754 \mathrm{a} 0$

17. Gray EE, Suzuki K, Cyster JG. Cutting edge: Identification of a motile IL-17producing gammadelta $\mathrm{T}$ cell population in the dermis. J Immunol. (2011) 186:6091-5. doi: 10.4049/jimmunol.1100427

18. Havran WL, Allison JP. Origin of Thy-1+ dendritic epidermal cells of adult mice from fetal thymic precursors. Nature (1990) 344:68-70. doi: $10.1038 / 344068 \mathrm{a} 0$.

19. Goodman T, Lefrancois L. Intraepithelial lymphocytes. Anatomical site, not $\mathrm{T}$ cell receptor form, dictates phenotype and function. J Exp Med. (1989) 170:1569-81

20. Garman RD, Doherty PJ, Raulet DH. Diversity, rearrangement, and expression of murine T cell gamma genes. Cell (1986) 45:733-42.

21. Nielsen MM, Witherden DA, Havran WL. gammadelta T cells in homeostasis and host defence of epithelial barrier tissues. Nat Rev Immunol. (2017) 17:733-45. doi: 10.1038/nri.2017.101

22. Li F, Hao X, Chen Y, Bai L, Gao X, Lian Z, et al. The microbiota maintain homeostasis of liver-resident gammadeltaT-17 cells in a lipid antigen/CD1d-dependent manner. Nat Commun. (2017) 7:13839. doi: $10.1038 /$ ncomms13839.
23. Duan J, Chung H, Troy E, Kasper DL. Microbial colonization drives expansion of IL-1 receptor 1-expressing and IL-17-producing gamma/delta T cells. Cell Host Microbe (2010) 7:140-50. doi: 10.1016/j.chom.2010.01.00.

24. St Leger AJ, Desai JV, Drummond RA, Kugadas A, Almaghrabi F, Silver P, et al. An Ocular Commensal Protects against Corneal Infection by Driving an Interleukin-17 Response from Mucosal gammadelta T Cells. Immunity (2017) 47:148-58 e5. doi: 10.1016/j.immuni.2017.06.014

25. Ramirez-Valle F, Gray EE, Cyster JG. Inflammation induces dermal $\mathrm{Vgamma4}^{+}$gammadeltaT17 memory-like cells that travel to distant skin and accelerate secondary IL-17-driven responses. Proc Natl Acad Sci USA. (2015) 112:8046-51. doi: 10.1073/pnas.1508990112

26. Hartwig T, Pantelyushin S, Croxford AL, Kulig P, Becher B. Dermal IL-17producing gammadelta T cells establish long-lived memory in the skin. Eur J Immunol. (2015) 45:3022-33. doi: 10.1002/eji.201545883

27. Benakis C, Brea D, Caballero S, Faraco G, Moore J, Murphy M, et al. Commensal microbiota affects ischemic stroke outcome by regulating intestinal gammadelta $\mathrm{T}$ cells. Nat Med. (2016) 22:516-23. doi: $10.1038 / \mathrm{nm} .4068$.

28. Cheng M, Qian L, Shen G, Bian G, Xu T, Xu W, et al. Microbiota modulate tumoral immune surveillance in lung through a gammadeltaT17 immune cell-dependent mechanism. Cancer Res. (2014) 74:4030-41. doi: 10.1158/0008-5472.CAN-13-2462

29. Wu P, Wu D, Ni C, Ye J, Chen W, Hu G, et al. gammadeltaT17 cells promote the accumulation and expansion of myeloid-derived suppressor cells in human colorectal cancer. Immunity (2014) 40:785-800. doi: 10.1016/j.immuni.2014.03.013

30. Lalor SJ, McLoughlin RM. Memory gammadelta T Cells-Newly Appreciated Protagonists in Infection and Immunity. Trends Immunol. (2016) 37:690702. doi: 10.1016/j.it.2016.07.006

31. O’Brien RL, Born WK. gammadelta T cell subsets: a link between TCR and function? Semin Immunol. (2010) 22:193-8. doi: 10.1016/j.smim.2010.03.006

32. Narayan K, Sylvia KE, Malhotra N, Yin CC, Martens G, Vallerskog T, et al. Intrathymic programming of effector fates in three molecularly distinct gammadelta T cell subtypes. Nat Immunol. (2012) 13:511-8. doi: $10.1038 /$ ni.2247

33. Willcox CR, Pitard V, Netzer S, Couzi L, Salim M, Silberzahn T, et al. Cytomegalovirus and tumor stress surveillance by binding of a human gammadelta $\mathrm{T}$ cell antigen receptor to endothelial protein $\mathrm{C}$ receptor. Nat Immunol. (2012) 13:872-9. doi: 10.1038/ni.2394

34. Dechanet J, Merville P, Lim A, Retiere C, Pitard V, Lafarge X, et al. Implication of gammadelta $\mathrm{T}$ cells in the human immune response to cytomegalovirus. J Clin Invest. (1999) 103:1437-49. doi: 10.1172/ JCI5409

35. Knight A, Madrigal AJ, Grace S, Sivakumaran J, Kottaridis P, Mackinnon S, et al. The role of Vdelta2-negative gammadelta T cells during cytomegalovirus reactivation in recipients of allogeneic stem cell transplantation. Blood (2010) 116:2164-72. doi: 10.1182/blood-2010-01-255166

36. Scheper W, van Dorp S, Kersting S, Pietersma F, Lindemans C, Hol $\mathrm{S}$, et al. gammadeltaT cells elicited by CMV reactivation after alloSCT cross-recognize CMV and leukemia. Leukemia. (2013) 27:1328-38. doi: 10.1038/leu.2012.374

37. Couzi L, Levaillant Y, Jamai A, Pitard V, Lassalle R, Martin K, et al. Cytomegalovirus-induced gammadelta $\mathrm{T}$ cells associate with reduced cancer risk after kidney transplantation. J Am Soc Nephrol. (2010) 21:181-8. doi: 10.1681/ASN.2008101072

38. Abate G, Eslick J, Newman FK, Frey SE, Belshe RB, Monath TP, et al. Flow-cytometric detection of vaccinia-induced memory effector CD4(+), CD8(+), and gamma delta TCR(+) T cells capable of antigenspecific expansion and effector functions. J Infect Dis. (2005) 192:1362-71. doi: $10.1086 / 444423$

39. Shao L, Huang D, Wei H, Wang RC, Chen CY, Shen L, et al. Expansion, reexpansion, and recall-like expansion of Vgamma2Vdelta2 $\mathrm{T}$ cells in smallpox vaccination and monkeypox virus infection. J Virol. (2009) 83:11959-65. doi: 10.1128/JVI.00689-09

40. Hviid L, Kurtzhals JA, Adabayeri V, Loizon S, Kemp K, Goka BQ, et al. Perturbation and proinflammatory type activation of $\mathrm{V}$ delta $1(+)$ gamma delta T cells in African children with Plasmodium falciparum malaria. Infect Immun. (2001) 69:3190-6. doi: 10.1128/IAI.69.5.3190-3196.2001 
41. Ho M, Tongtawe P, Kriangkum J, Wimonwattrawatee T, Pattanapanyasat K, Bryant L, et al. Polyclonal expansion of peripheral gamma delta $\mathrm{T}$ cells in human Plasmodium falciparum malaria. Infect Immun. (1994) 62:855-62.

42. Roussilhon C, Agrapart M, Guglielmi P, Bensussan A, Brasseur P, Ballet JJ. Human TcR gamma delta+ lymphocyte response on primary exposure to Plasmodium falciparum. Clin Exp Immunol. (1994) 95:91-7.

43. Teirlinck AC, McCall MB, Roestenberg M, Scholzen A, Woestenenk R, de Mast Q, et al. Longevity and composition of cellular immune responses following experimental Plasmodium falciparum malaria infection in humans. PLoS Pathog. (2011) 7:e1002389. doi: 10.1371/journal.ppat.1002389

44. Mamedov MR, Scholzen A, Nair RV, Cumnock K, Kenkel JA, Oliveira JHM, et al. A Macrophage Colony-Stimulating-Factor-Producing gammadelta T Cell Subset Prevents Malarial Parasitemic Recurrence. Immunity (2018) 48:350-63 e7. doi: 10.1016/j.immuni.2018.01.009

45. Shen Y, Zhou D, Qiu L, Lai X, Simon M, Shen L, et al. Adaptive immune response of Vgamma2Vdelta2 $+\mathrm{T}$ cells during mycobacterial infections. Science (2002) 295:2255-8. doi: 10.1126/science.1068819

46. Shen H, Wang Y, Chen CY, Frencher J, Huang D, Yang E, et al. Th17-related cytokines contribute to recall-like expansion/effector function of HMBPPspecific Vgamma2Vdelta2 T cells after Mycobacterium tuberculosis infection or vaccination. Eur J Immunol. (2015) 45:442-51. doi: 10.1002/eji.201444635

47. Huang D, Shen Y, Qiu L, Chen CY, Shen L, Estep J, et al. Immune distribution and localization of phosphoantigen-specific Vgamma2Vdelta2 $\mathrm{T}$ cells in lymphoid and nonlymphoid tissues in Mycobacterium tuberculosis infection. Infect Immun. (2008) 76:426-36. doi: 10.1128/IAI.01008-07

48. Misiak A, Wilk MM, Raverdeau M, Mills KH. IL-17-Producing Innate and Pathogen-Specific Tissue Resident Memory gammadelta T Cells Expand in the Lungs of Bordetella pertussis-Infected Mice. J Immunol. (2017) 198:36374. doi: 10.4049/jimmunol.1601024

49. Murphy AG, O'Keeffe KM, Lalor SJ, Maher BM, Mills KH, McLoughlin RM. Staphylococcus aureus infection of mice expands a population of memory gammadelta $\mathrm{T}$ cells that are protective against subsequent infection. J Immunol. (2014) 192:3697-708. doi: 10.4049/jimmunol.1303420

50. Dillen CA, Pinsker BL, Marusina AI, Merleev AA, Farber ON, Liu H, et al. Clonally expanded gammadelta $\mathrm{T}$ cells protect against Staphylococcus aureus skin reinfection. J Clin Invest. (2018) 128:1026-42. doi: 10.1172/JCI96481

51. Jiang X, Park CO, Geddes Sweeney J, Yoo MJ, Gaide O, Kupper TS. Dermal gammadelta $T$ Cells Do Not Freely Re-Circulate Out of Skin and Produce IL-17 to Promote Neutrophil Infiltration during Primary Contact Hypersensitivity. PLoS ONE (2017) 12:e0169397. doi: 10.1371/journal.pone.0169397

52. Lo Presti E, Toia F, Oieni S, Buccheri S, Turdo A, Mangiapane LR, et al. Squamous Cell Tumors Recruit gammadelta T Cells Producing either IL17 or IFNgamma Depending on the Tumor Stage. Cancer Immunol Res. (2017) 5:397-407. doi: 10.1158/2326-6066.CIR-16-0348

53. Cordova A, Toia F, La Mendola C, Orlando V, Meraviglia S, Rinaldi $\mathrm{G}$, et al. Characterization of human gammadelta $\mathrm{T}$ lymphocytes infiltrating primary malignant melanomas. PLoS ONE (2012) 7:e49878. doi: 10.1371/journal.pone.0049878

54. Jameson J, Ugarte K, Chen N, Yachi P, Fuchs E, Boismenu R, et al. A role for skin gammadelta T cells in wound repair. Science (2002) 296:747-9. doi: 10.1126/science.1069639

55. Girardi M, Lewis J, Glusac E, Filler RB, Geng L, Hayday AC, et al. Resident skin-specific gammadelta $\mathrm{T}$ cells provide local, nonredundant regulation of cutaneous inflammation. J Exp Med. (2002) 195:855-67. doi: 10.1084/jem.20012000

56. Cho JS, Pietras EM, Garcia NC, Ramos RI, Farzam DM, Monroe HR, et al. IL-17 is essential for host defense against cutaneous Staphylococcus aureus infection in mice. J Clin Invest. (2010) 120:1762-73. doi: 10.1172/JCI40891

57. Girardi M, Oppenheim DE, Steele CR, Lewis JM, Glusac E, Filler R, et al. Regulation of cutaneous malignancy by gammadelta T cells. Science (2001) 294:605-9. doi: 10.1126/science.1063916

58. Strid J, Roberts SJ, Filler RB, Lewis JM, Kwong BY, Schpero W, et al. Acute upregulation of an NKG2D ligand promotes rapid reorganization of a local immune compartment with pleiotropic effects on carcinogenesis. Nat Immunol. (2008) 9:146-54. doi: 10.1038/ni1556

59. Ryan-Payseur B, Frencher J, Shen L, Chen CY, Huang D, Chen ZW. Multieffector-functional immune responses of HMBPP-specific
Vgamma2Vdelta2 $\mathrm{T}$ cells in nonhuman primates inoculated with Listeria monocytogenes DeltaactA prfA*. J Immunol. (2012) 189:1285-93. doi: 10.4049/jimmunol.1200641

60. Frencher JT, Shen H, Yan L, Wilson JO, Freitag NE, Rizzo AN, et al. HMBPP-deficient Listeria mutant immunization alters pulmonary/systemic responses, effector functions, and memory polarization of Vgamma2Vdelta2 T cells. J Leukoc Biol. (2014) 96:957-67. doi: 10.1189/jlb.6HI1213-632R

61. Schmolka N, Papotto PH, Romero PV, Amado T, Enguita FJ, Amorim A, et al. MicroRNA-146a controls functional plasticity in gammadelta T cells by targeting NOD1. Sci Immunol. (2018) 3:eaao1392. doi: 10.1126/sciimmunol.aao1392

62. Sheridan BS, Romagnoli PA, Pham QM, Fu HH, Alonzo F, 3rd, Schubert WD, et al. gammadelta $\mathrm{T}$ cells exhibit multifunctional and protective memory in intestinal tissues. Immunity (2013) 39:184-95. doi: 10.1016/j.immuni.2013.06.015

63. Giacomelli R, Parzanese I, Frieri G, Passacantando A, Pizzuto F, Pimpo T, et al. Increase of circulating gamma/delta $\mathrm{T}$ lymphocytes in the peripheral blood of patients affected by active inflammatory bowel disease. Clin Exp Immunol. (1994) 98:83-8.

64. McVay LD, Li B, Biancaniello R, Creighton MA, Bachwich D, Lichtenstein G, et al. Changes in human mucosal gamma delta $\mathrm{T}$ cell repertoire and function associated with the disease process in inflammatory bowel disease. Mol Med. (1997) 3:183-203.

65. Meraviglia S, Lo Presti E, Tosolini M, La Mendola C, Orlando V, Todaro $\mathrm{M}$, et al. Distinctive features of tumor-infiltrating gammadelta $\mathrm{T}$ lymphocytes in human colorectal cancer. Oncoimmunology (2017) 6:e1347742. doi: 10.1080/2162402X.2017.1347742

66. Hoytema van Konijnenburg DP, Reis BS, Pedicord VA, Farache J, Victora GD, Mucida D. Intestinal Epithelial and Intraepithelial T Cell Crosstalk Mediates a Dynamic Response to Infection. Cell (2017) 171:783-94 e13. doi: 10.1016/j.cell.2017.08.046

67. Dalton JE, Cruickshank SM, Egan CE, Mears R, Newton DJ, Andrew EM, et al. Intraepithelial gammadelta+ lymphocytes maintain the integrity of intestinal epithelial tight junctions in response to infection. Gastroenterology (2006) 131:818-29. doi: 10.1053/j.gastro.2006.06.003

68. Ismail AS, Severson KM, Vaishnava S, Behrendt CL, Yu X, Benjamin JL, et al. Gammadelta intraepithelial lymphocytes are essential mediators of hostmicrobial homeostasis at the intestinal mucosal surface. Proc Natl Acad Sci USA. (2011) 108:8743-8. doi: 10.1073/pnas.1019574108

69. Edelblum KL, Singh G, Odenwald MA, Lingaraju A, El Bissati K, McLeod R, et al. gammadelta Intraepithelial Lymphocyte Migration Limits Transepithelial Pathogen Invasion and Systemic Disease in Mice. Gastroenterology (2015) 148:1417-26. doi: 10.1053/j.gastro.2015.02.053

70. Coffelt SB, Kersten K, Doornebal CW, Weiden J, Vrijland K, Hau CS, et al. IL-17-producing gammadelta $\mathrm{T}$ cells and neutrophils conspire to promote breast cancer metastasis. Nature (2015) 522:345-8. doi: 10.1038/nature 14282

71. Fisher JP, Yan M, Heuijerjans J, Carter L, Abolhassani A, Frosch J, et al. Neuroblastoma killing properties of Vdelta2 and Vdelta2-negative gammadeltaT cells following expansion by artificial antigen-presenting cells. Clin Cancer Res. (2014) 20:5720-32. doi: 10.1158/1078-0432.CCR-13-3464

72. Sutton CE, Lalor SJ, Sweeney CM, Brereton CF, Lavelle EC, Mills KH. Interleukin-1 and IL-23 induce innate IL-17 production from gammadelta T cells, amplifying Th17 responses and autoimmunity. Immunity (2009) 31:331-41. doi: 10.1016/j.immuni.2009.08.001

73. Ito Y, Usui T, Kobayashi S, Iguchi-Hashimoto M, Ito H, Yoshitomi H, et al. Gamma/delta T cells are the predominant source of interleukin-17 in affected joints in collagen-induced arthritis, but not in rheumatoid arthritis. Arthritis Rheum. (2009) 60:2294-303. doi: 10.1002/art.24687

74. Kenna TJ, Davidson SI, Duan R, Bradbury LA, McFarlane J, Smith M, et al. Enrichment of circulating interleukin-17-secreting interleukin-23 receptorpositive gamma/delta $\mathrm{T}$ cells in patients with active ankylosing spondylitis. Arthritis Rheum. (2012) 64:1420-9. doi: 10.1002/art.33507

75. Nian H, Shao H, O'Brien RL, Born WK, Kaplan HJ, Sun D. Activated gammadelta $\mathrm{T}$ cells promote the activation of uveitogenic $\mathrm{T}$ cells and exacerbate EAU development. Invest Ophthalmol Vis Sci. (2011) 52:5920-7. doi: $10.1167 /$ iovs.10-6758 
76. Carding SR, Kyes S, Jenkinson EJ, Kingston R, Bottomly K, Owen JJ, et al. Developmentally regulated fetal thymic and extrathymic T-cell receptor gamma delta gene expression. Genes Dev. (1990) 4:1304-15.

77. Munoz-Ruiz M, Sumaria N, Pennington DJ, Silva-Santos B. Thymic Determinants of gammadelta T Cell Differentiation. Trends Immunol. (2017) 38:336-44. doi: 10.1016/j.it.2017.01.007

78. Papotto PH, Ribot JC, Silva-Santos B. IL-17(+) gammadelta T cells as kick-starters of inflammation. Nat Immunol. (2017) 18:604-11. doi: $10.1038 /$ ni.3726

79. Asarnow DM, Goodman T, LeFrancois L, Allison JP. Distinct antigen receptor repertoires of two classes of murine epithelium-associated T cells. Nature (1989) 341:60-2. doi: 10.1038/341060a0

80. Turchinovich G, Hayday AC. Skint-1 identifies a common molecular mechanism for the development of interferon-gamma-secreting versus interleukin-17-secreting gammadelta T cells. Immunity (2011) 35:59-68. doi: 10.1016/j.immuni.2011.04.018

81. Witherden DA, Verdino P, Rieder SE, Garijo O, Mills RE, Teyton L, et al. The junctional adhesion molecule JAML is a costimulatory receptor for epithelial gammadelta T cell activation. Science (2010) 329:1205-10. doi: 10.1126/science.1192698

82. Dalessandri T, Crawford G, Hayes M, Castro Seoane R, Strid J. IL13 from intraepithelial lymphocytes regulates tissue homeostasis and protects against carcinogenesis in the skin. Nat Commun. (2016) 7:12080. doi: $10.1038 /$ ncomms 12080

83. Boismenu R, Havran WL. Modulation of epithelial cell growth by intraepithelial gamma delta T cells. Science (1994) 266:1253-5.

84. Sharp LL, Jameson JM, Cauvi G, Havran WL. Dendritic epidermal T cells regulate skin homeostasis through local production of insulin-like growth factor 1. Nat Immunol. (2005) 6:73-9. doi: 10.1038/ni1152

85. Chien YH, Zeng X, Prinz I. The natural and the inducible: interleukin (IL)-17-producing gammadelta T cells. Trends Immunol. (2013) 34:151-4. doi: $10.1016 /$ j.it.2012.11.004

86. Haas JD, Ravens S, Duber S, Sandrock I, Oberdorfer L, Kashani E, et al. Development of interleukin-17-producing gammadelta $\mathrm{T}$ cells is restricted to a functional embryonic wave. Immunity (2012) 37:48-59. doi: 10.1016/j.immuni.2012.06.003

87. Wencker M, Turchinovich G, Di Marco Barros R, Deban L, Jandke A, Cope $\mathrm{A}$, et al. Innate-like $\mathrm{T}$ cells straddle innate and adaptive immunity by altering antigen-receptor responsiveness. Nat Immunol. (2014) 15:80-7. doi: $10.1038 /$ ni. 2773

88. Martin B, Hirota K, Cua DJ, Stockinger B, Veldhoen M. Interleukin17-producing gammadelta $\mathrm{T}$ cells selectively expand in response to pathogen products and environmental signals. Immunity (2009) 31:321-30. doi: 10.1016/j.immuni.2009.06.020

89. Ribot JC, Chaves-Ferreira M, d'Orey F, Wencker M, Goncalves-Sousa $\mathrm{N}$, Decalf J, et al. Cutting edge: adaptive versus innate receptor signals selectively control the pool sizes of murine IFN-gamma- or IL-17producing gammadelta T cells upon infection. J Immunol. (2010) 185:64215. doi: 10.4049/jimmunol.1002283

90. Barros-Martins J, Schmolka N, Fontinha D, Pires de Miranda M, Simas JP, Brok I, et al. Effector gammadelta T Cell Differentiation Relies on Master but Not Auxiliary Th Cell Transcription Factors. J Immunol. (2016) 196:3642-52. doi: 10.4049/jimmunol.1501921

91. Haas JD, Gonzalez FH, Schmitz S, Chennupati V, Fohse L, Kremmer E, et al. CCR6 and NK1.1 distinguish between IL-17A and IFN-gammaproducing gammadelta effector T cells. Eur J Immunol. (2009) 39:3488-97. doi: 10.1002/eji.200939922

92. Kisielow J, Kopf M, Karjalainen K. SCART scavenger receptors identify a novel subset of adult gammadelta T cells. J Immunol. (2008) 181:1710-6. doi: 10.4049/jimmunol.181.3.1710

93. Shibata K, Yamada H, Nakamura R, Sun X, Itsumi M, Yoshikai Y. Identification of CD25+ gamma delta $\mathrm{T}$ cells as fetal thymus-derived naturally occurring IL-17 producers. I Immunol. (2008) 181:5940-7. doi: 10.4049/jimmunol.181.9.5940

94. Ribot JC, deBarros A, Pang DJ, Neves JF, Peperzak V, Roberts SJ, et al. CD27 is a thymic determinant of the balance between interferon-gamma- and interleukin 17-producing gammadelta T cell subsets. Nat Immunol. (2009) 10:427-36. doi: 10.1038/ni.1717
95. Jensen KD, Su X, Shin S, Li L, Youssef S, Yamasaki S, et al. Thymic selection determines gammadelta $\mathrm{T}$ cell effector fate: antigennaive cells make interleukin-17 and antigen-experienced cells make interferon gamma. Immunity (2008) 29:90-100. doi: 10.1016/j.immuni.2008. 04.022

96. Fahl SP, Coffey F, Kain L, Zarin P, Dunbrack RL, Jr., Teyton L, et al. Role of a selecting ligand in shaping the murine gammadelta-TCR repertoire. Proc Natl Acad Sci USA. (2018) 115:1889-94. doi: 10.1073/pnas.1718328115

97. Coffey F, Lee SY, Buus TB, Lauritsen JP, Wong GW, Joachims ML, et al. The TCR ligand-inducible expression of CD73 marks gammadelta lineage commitment and a metastable intermediate in effector specification. J Exp Med. (2014) 211:329-43. doi: 10.1084/jem.20131540

98. Munoz-Ruiz M, Ribot JC, Grosso AR, Goncalves-Sousa N, Pamplona A, Pennington DJ, et al. TCR signal strength controls thymic differentiation of discrete proinflammatory gammadelta T cell subsets. Nat Immunol. (2016) 17:721-7. doi: 10.1038/ni.3424

99. Sumaria N, Grandjean CL, Silva-Santos B, Pennington DJ. Strong TCRgammadelta Signaling Prohibits Thymic Development of IL17A-Secreting gammadelta $\mathrm{T}$ Cells. Cell Rep. (2017) 19:2469-76. doi: 10.1016/j.celrep.2017.05.071

100. Colpitts SL, Puddington L, Lefrancois L. IL-15 receptor alpha signaling constrains the development of IL-17-producing gammadelta T cells. Proc Natl Acad Sci USA. (2015) 112:9692-7. doi: 10.1073/pnas.1420741112

101. Michel ML, Pang DJ, Haque SF, Potocnik AJ, Pennington DJ, Hayday AC. Interleukin 7 (IL-7) selectively promotes mouse and human IL-17producing gammadelta cells. Proc Natl Acad Sci USA. (2012) 109:17549-54. doi: $10.1073 /$ pnas. 1204327109

102. Schmolka N, Serre K, Grosso AR, Rei M, Pennington DJ, Gomes AQ, et al. Epigenetic and transcriptional signatures of stable versus plastic differentiation of proinflammatory gammadelta T cell subsets. Nat Immunol. (2013) 14:1093-100. doi: 10.1038/ni.2702

103. Zeng X, Wei YL, Huang J, Newell EW, Yu H, Kidd BA, et al. gammadelta $\mathrm{T}$ cells recognize a microbial encoded $\mathrm{B}$ cell antigen to initiate a rapid antigen-specific interleukin-17 response. Immunity (2012) 37:524-34. doi: 10.1016/j.immuni.2012.06.011

104. Muschaweckh A, Petermann F, Korn T. IL-1beta and IL-23 Promote Extrathymic Commitment of CD27(+)CD122(-) gammadelta T Cells to gammadeltaT17 Cells. J Immunol. (2017) 199:2668-79. doi: 10.4049/jimmunol.1700287

105. Papotto PH, Goncalves-Sousa N, Schmolka N, Iseppon A, Mensurado S, Stockinger B, et al. IL-23 drives differentiation of peripheral gammadelta17 T cells from adult bone marrow-derived precursors. EMBO Rep. (2017) 18:1957-67. doi: 10.15252/embr.201744200

106. McVay LD, Carding SR, Bottomly K, Hayday AC. Regulated expression and structure of $\mathrm{T}$ cell receptor gamma/delta transcripts in human thymic ontogeny. EMBO J. (1991) 10:83-91.

107. McVay LD, Carding SR. Extrathymic origin of human gamma delta T cells during fetal development. J Immunol. (1996) 157:2873-82.

108. Parker CM, Groh V, Band H, Porcelli SA, Morita C, Fabbi M, et al. Evidence for extrathymic changes in the $\mathrm{T}$ cell receptor gamma/delta repertoire. J Exp Med. (1990) 171:1597-612.

109. De Libero G, Casorati G, Giachino C, Carbonara C, Migone N, Matzinger $\mathrm{P}$, et al. Selection by two powerful antigens may account for the presence of the major population of human peripheral gamma/delta T cells. J Exp Med. (1991) 173:1311-22.

110. Dimova $\mathrm{T}$, Brouwer $\mathrm{M}$, Gosselin F, Tassignon J, Leo O, Donner $\mathrm{C}$, et al. Effector Vgamma9Vdelta2 $\mathrm{T}$ cells dominate the human fetal gammadelta T-cell repertoire. Proc Natl Acad Sci USA. (2015) 112:E556-65. doi: 10.1073/pnas.1412058112

111. Morita CT, Jin C, Sarikonda G, Wang H. Nonpeptide antigens, presentation mechanisms, and immunological memory of human Vgamma2Vdelta2 T cells: discriminating friend from foe through the recognition of prenyl pyrophosphate antigens. Immunol Rev. (2007) 215:59-76. doi: 10.1111/j.1600-065X.2006.00479.x

112. Harly C, Guillaume Y, Nedellec S, Peigne CM, Monkkonen H, Monkkonen J, et al. Key implication of CD277/butyrophilin-3 (BTN3A) in cellular stress sensing by a major human gammadelta T-cell subset. Blood (2012) 120:226979. doi: 10.1182/blood-2012-05-430470 
113. Wang H, Henry O, Distefano MD, Wang YC, Raikkonen J, Monkkonen J, et al. Butyrophilin 3A1 plays an essential role in prenyl pyrophosphate stimulation of human Vgamma2Vdelta2 T cells. J Immunol. (2013) 191:1029-42. doi: 10.4049/jimmunol.1300658

114. Vavassori S, Kumar A, Wan GS, Ramanjaneyulu GS, Cavallari M, El Daker $\mathrm{S}$, et al. Butyrophilin 3A1 binds phosphorylated antigens and stimulates human gammadelta T cells. Nat Immunol. (2013) 14:908-16. doi: 10.1038/ ni.2665

115. Vantourout P, Laing A, Woodward MJ, Zlatareva I, Apolonia L, Jones AW, et al. Heteromeric interactions regulate butyrophilin (BTN) and BTN-like molecules governing gammadelta T cell biology. Proc Natl Acad Sci USA. (2018) 115:1039-44. doi: 10.1073/pnas.1701237115

116. De Rosa SC, Andrus JP, Perfetto SP, Mantovani JJ, Herzenberg LA, Herzenberg LA, et al. Ontogeny of gamma delta $\mathrm{T}$ cells in humans. $J$ Immunol. (2004) 172:1637-45. doi: 10.4049/jimmunol.172.3.1637

117. Dieli F, Poccia F, Lipp M, Sireci G, Caccamo N, Di Sano C, et al. Differentiation of effector/memory Vdelta2 $\mathrm{T}$ cells and migratory routes in lymph nodes or inflammatory sites. J Exp Med. (2003) 198:391-7. doi: 10.1084/jem.20030235

118. Holtmeier W, Pfander M, Hennemann A, Zollner TM, Kaufmann R, Caspary WF. The TCR-delta repertoire in normal human skin is restricted and distinct from the TCR-delta repertoire in the peripheral blood. I Invest Dermatol. (2001) 116:275-80. doi: 10.1046/j.1523-1747.2001.01250.x

119. Deusch K, Luling F, Reich K, Classen M, Wagner H, Pfeffer K. A major fraction of human intraepithelial lymphocytes simultaneously expresses the gamma/delta $\mathrm{T}$ cell receptor, the CD8 accessory molecule and preferentially uses the V delta 1 gene segment. Eur J Immunol. (1991) 21:1053-9. doi: 10.1002/eji.1830210429

120. Hunter S, Willcox CR, Davey MS, Kasatskaya SA, Jeffery HC, Chudakov $\mathrm{DM}$, et al. Human liver infiltrating gammadelta $\mathrm{T}$ cells are composed of clonally expanded circulating and tissue-resident populations. J Hepatol. (2018) 69:654-65. doi: 10.1016/j.jhep.2018.05.007

121. Luoma AM, Castro CD, Mayassi T, Bembinster LA, Bai L, Picard D, et al. Crystal structure of Vdelta1 $\mathrm{T}$ cell receptor in complex with CD1d-sulfatide shows MHC-like recognition of a self-lipid by human gammadelta $\mathrm{T}$ cells. Immunity (2013) 39:1032-42. doi: 10.1016/j.immuni.2013.11.001

122. Uldrich AP, Le Nours J, Pellicci DG, Gherardin NA, McPherson KG, Lim RT, et al. CD1d-lipid antigen recognition by the gammadelta TCR. Nat Immunol. (2013) 14:1137-45. doi: 10.1038/ni.2713

123. Marlin R, Pappalardo A, Kaminski H, Willcox CR, Pitard V, Netzer $\mathrm{S}$, et al. Sensing of cell stress by human gammadelta TCR-dependent recognition of annexin A2. Proc Natl Acad Sci USA. (2017) 114:3163-8. doi: 10.1073/pnas.1621052114

124. Davey MS, Willcox CR, Joyce SP, Ladell K, Kasatskaya SA, McLaren JE, et al. Clonal selection in the human Vdeltal $\mathrm{T}$ cell repertoire indicates gammadelta TCR-dependent adaptive immune surveillance. Nat Commun. (2017) 8:14760. doi: 10.1038/ncomms 14760

125. Pitard V, Roumanes D, Lafarge X, Couzi L, Garrigue I, Lafon ME, et al. Long-term expansion of effector/memory Vdelta2-gammadelta $\mathrm{T}$ cells is a specific blood signature of CMV infection. Blood (2008) 112:1317-24. doi: 10.1182/blood-2008-01-136713

126. Ravens S, Schultze-Florey C, Raha S, Sandrock I, Drenker M, Oberdorfer $\mathrm{L}$, et al. Human gammadelta $\mathrm{T}$ cells are quickly reconstituted after stemcell transplantation and show adaptive clonal expansion in response to viral infection. Nat Immunol. (2017) 18:393-401. doi: 10.1038/ni. 3686

127. Couzi L, Pitard V, Netzer S, Garrigue I, Lafon ME, Moreau JF, et al. Common features of gammadelta $\mathrm{T}$ cells and $\mathrm{CD} 8(+)$ alphabeta $\mathrm{T}$ cells responding to human cytomegalovirus infection in kidney transplant recipients. J Infect Dis. (2009) 200:1415-24. doi: 10.1086/644509

128. Halary F, Pitard V, Dlubek D, Krzysiek R, de la Salle H, Merville P, et al. Shared reactivity of $\mathrm{V}\{$ delta\}2(neg) \{gamma\}\{delta\} $\mathrm{T}$ cells against cytomegalovirus-infected cells and tumor intestinal epithelial cells. J Exp Med. (2005) 201:1567-78. doi: 10.1084/jem.20041851

129. Komano H, Fujiura Y, Kawaguchi M, Matsumoto S, Hashimoto Y, Obana S, et al. Homeostatic regulation of intestinal epithelia by intraepithelial gamma delta T cells. Proc Natl Acad Sci USA. (1995) 92:6147-51.
130. Kohlgruber AC, Gal-Oz ST, LaMarche NM, Shimazaki M, Duquette D, Nguyen $\mathrm{HN}$, et al. gammadelta T cells producing interleukin-17A regulate adipose regulatory $\mathrm{T}$ cell homeostasis and thermogenesis. Nat Immunol. (2018) 19:464-74. doi: 10.1038/s41590-018-0094-2

131. Vantourout P, Hayday A. Six-of-the-best: unique contributions of gammadelta T cells to immunology. Nat Rev Immunol. (2013) 13:88-100. doi: $10.1038 /$ nri3384

132. Liuzzi AR, Kift-Morgan A, Lopez-Anton M, Friberg IM, Zhang J, Brook AC, et al. Unconventional human $\mathrm{T}$ cells accumulate at the site of infection in response to microbial ligands and induce local tissue remodeling. J Immunol. (2016) 197:2195-207. doi: 10.4049/jimmunol.1600990

133. Caccamo N, La Mendola C, Orlando V, Meraviglia S, Todaro M, Stassi $\mathrm{G}$, et al. Differentiation, phenotype, and function of interleukin-17producing human Vgamma9Vdelta2 T cells. Blood (2011) 118:129-38. doi: 10.1182/blood-2011-01-331298

134. Romagnoli PA, Sheridan BS, Pham QM, Lefrancois L, Khanna KM. IL17A-producing resident memory gammadelta $\mathrm{T}$ cells orchestrate the innate immune response to secondary oral Listeria monocytogenes infection. Proc Natl Acad Sci USA. (2016) 113:8502-7. doi: 10.1073/pnas.16007 13113

135. Cai Y, Shen X, Ding C, Qi C, Li K, Li X, et al. Pivotal role of dermal IL17-producing gammadelta $\mathrm{T}$ cells in skin inflammation. Immunity (2011) 35:596-610. doi: 10.1016/j.immuni.2011.08.001

136. Gober HJ, Kistowska M, Angman L, Jeno P, Mori L, De Libero G. Human $\mathrm{T}$ cell receptor gammadelta cells recognize endogenous mevalonate metabolites in tumor cells. J Exp Med. (2003) 197:163-8. doi: 10.1084/jem.20021500

137. Dieli F, Vermijlen D, Fulfaro F, Caccamo N, Meraviglia S, Cicero G, et al. Targeting human \{gamma\}delta\} $\mathrm{T}$ cells with zoledronate and interleukin2 for immunotherapy of hormone-refractory prostate cancer. Cancer Res. (2007) 67:7450-7. doi: 10.1158/0008-5472.CAN-07-0199

138. Rei M, Goncalves-Sousa N, Lanca T, Thompson RG, Mensurado S, Balkwill FR, et al. Murine CD27(-) Vgamma6(+) gammadelta T cells producing IL$17 \mathrm{~A}$ promote ovarian cancer growth via mobilization of protumor small peritoneal macrophages. Proc Natl Acad Sci USA. (2014) 111:E3562-70. doi: 10.1073/pnas.1403424111

139. Bhagat G, Naiyer AJ, Shah JG, Harper J, Jabri B, Wang TC, et al. Small intestinal CD8+TCRgammadelta+NKG2A + intraepithelial lymphocytes have attributes of regulatory cells in patients with celiac disease. J Clin Invest. (2008) 118:281-93. doi: 10.1172/JCI30989

140. Peng G, Wang HY, Peng W, Kiniwa Y, Seo KH, Wang RF. Tumorinfiltrating gammadelta $\mathrm{T}$ cells suppress $\mathrm{T}$ and dendritic cell function via mechanisms controlled by a unique toll-like receptor signaling pathway. Immunity (2007) 27:334-48. doi: 10.1016/j.immuni.2007. 05.020

141. Chen Y, Chou K, Fuchs E, Havran WL, Boismenu R. Protection of the intestinal mucosa by intraepithelial gamma delta T cells. Proc Natl Acad Sci USA. (2002) 99:14338-43. doi: 10.1073/pnas.212290499

142. Havran WL, Allison JP. Developmentally ordered appearance of thymocytes expressing different T-cell antigen receptors. Nature (1988) 335:443-5. doi: $10.1038 / 335443 \mathrm{a} 0$

143. Xiong N, Raulet DH. Development and selection of gammadelta T cells. Immunol Rev. (2007) 215:15-31. doi: 10.1111/j.1600-065X.2006.00478.x

144. Lewis JM, Girardi M, Roberts SJ, Barbee SD, Hayday AC, Tigelaar RE. Selection of the cutaneous intraepithelial gammadelta $+\mathrm{T}$ cell repertoire by a thymic stromal determinant. Nat Immunol. (2006) 7:843-50. doi: $10.1038 /$ ni1363

145. Boyden LM, Lewis JM, Barbee SD, Bas A, Girardi M, Hayday AC, et al. Skint1, the prototype of a newly identified immunoglobulin superfamily gene cluster, positively selects epidermal gammadelta T cells. Nat Genet. (2008) 40:656-62. doi: $10.1038 /$ ng.108

146. Barbee SD, Woodward MJ, Turchinovich G, Mention JJ, Lewis JM, Boyden LM, et al. Skint-1 is a highly specific, unique selecting component for epidermal T cells. Proc Natl Acad Sci USA. (2011) 108:3330-5. doi: 10.1073/pnas.1010890108

147. Jin Y, Xia M, Saylor CM, Narayan K, Kang J, Wiest DL, et al. Cutting edge: Intrinsic programming of thymic gammadeltaT cells for 
specific peripheral tissue localization. J Immunol. (2010) 185:7156-60. doi: 10.4049/jimmunol.1002781

148. Kawai K, Kishihara K, Molina TJ, Wallace VA, Mak TW, Ohashi PS. Impaired development of $\mathrm{V}$ gamma 3 dendritic epidermal $\mathrm{T}$ cells in p56lck protein tyrosine kinase-deficient and CD45 protein tyrosine phosphatase-deficient mice. J Exp Med. (1995) 181:345-9.

149. Mallick-Wood CA, Pao W, Cheng AM, Lewis JM, Kulkarni S, Bolen JB, et al. Disruption of epithelial gamma delta $\mathrm{T}$ cell repertoires by mutation of the Syk tyrosine kinase. Proc Natl Acad Sci USA. (1996) 93:9704-9.

150. Kadlecek TA, van Oers NS, Lefrancois L, Olson S, Finlay D, Chu DH, et al. Differential requirements for ZAP-70 in TCR signaling and T cell development. J Immunol. (1998) 161:4688-94.

151. Endo Y, Ishikawa O, Negishi I. Zeta-chain-associated protein-70 molecule is essential for the proliferation and the final maturation of dendritic epidermal T cells. Exp Dermatol. (2005) 14:188-93. doi: 10.1111/j.0906-6705.2005.00264.x

152. Xiong N, Kang C, Raulet DH. Positive selection of dendritic epidermal gammadelta $\mathrm{T}$ cell precursors in the fetal thymus determines expression of skin-homing receptors. Immunity (2004) 21:121-31. doi: 10.1016/j.immuni.2004.06.008

153. Xia M, Qi Q, Jin Y, Wiest DL, August A, Xiong N. Differential roles of IL2-inducible T cell kinase-mediated TCR signals in tissue-specific localization and maintenance of skin intraepithelial T cells. J Immunol. (2010) 184:680714. doi: 10.4049/jimmunol.1000453

154. Jiang X, Campbell JJ, Kupper TS. Embryonic trafficking of gammadelta T cells to skin is dependent on E/P selectin ligands and CCR4. Proc Natl Acad Sci USA. (2010) 107:7443-8. doi: 10.1073/pnas.0912943107

155. Chodaczek G, Papanna V, Zal MA, Zal T. Body-barrier surveillance by epidermal gammadelta TCRs. Nat Immunol. (2012) 13:272-82. doi: $10.1038 /$ ni. 2240

156. Jameson JM, Cauvi G, Witherden DA, Havran WL. A keratinocyteresponsive gamma delta TCR is necessary for dendritic epidermal T cell activation by damaged keratinocytes and maintenance in the epidermis. $J$ Immunol. (2004) 172:3573-9. doi: 10.4049/jimmunol.172.6.3573

157. Komori HK, Witherden DA, Kelly R, Sendaydiego K, Jameson JM, Teyton L, et al. Cutting edge: dendritic epidermal gammadelta $\mathrm{T}$ cell ligands are rapidly and locally expressed by keratinocytes following cutaneous wounding. J Immunol. (2012) 188:2972-6. doi: 10.4049/jimmunol.11 00887

158. Strid J, Sobolev O, Zafirova B, Polic B, Hayday A. The intraepithelial T cell response to NKG2D-ligands links lymphoid stress surveillance to atopy. Science (2011) 334:1293-7. doi: 10.1126/science.1211250

159. Havran WL, Chien YH, Allison JP. Recognition of self antigens by skinderived T cells with invariant gamma delta antigen receptors. Science (1991) 252:1430-2.

160. Witherden DA, Watanabe M, Garijo O, Rieder SE, Sarkisyan G, Cronin SJ, et al. The CD100 receptor interacts with its plexin B2 ligand to regulate epidermal gammadelta T cell function. Immunity (2012) 37:314-25. doi: 10.1016/j.immuni.2012.05.026

161. Whang MI, Guerra N, Raulet DH. Costimulation of dendritic epidermal gammadelta $\mathrm{T}$ cells by a new NKG2D ligand expressed specifically in the skin. J Immunol. (2009) 182:4557-64. doi: 10.4049/jimmunol.08 02439

162. Yoshida S, Mohamed RH, Kajikawa M, Koizumi J, Tanaka M, Fugo $\mathrm{K}$, et al. Involvement of an NKG2D ligand $\mathrm{H} 60 \mathrm{c}$ in epidermal dendritic T cell-mediated wound repair. J Immunol. (2012) 188:3972-9. doi: $10.4049 /$ jimmunol.1102886

163. MacLeod AS, Hemmers S, Garijo O, Chabod M, Mowen K, Witherden $\mathrm{DA}$, et al. Dendritic epidermal $\mathrm{T}$ cells regulate skin antimicrobial barrier function. J Clin Invest. (2013) 123:4364-74. doi: 10.1172/JCI 70064

164. Boismenu R, Feng L, Xia YY, Chang JC, Havran WL. Chemokine expression by intraepithelial gamma delta $\mathrm{T}$ cells. Implications for the recruitment of inflammatory cells to damaged epithelia. J Immunol. (1996) 157:985-92.

165. MacLeod AS, Rudolph R, Corriden R, Ye I, Garijo O, Havran WL. Skin-resident $\mathrm{T}$ cells sense ultraviolet radiation-induced injury and contribute to DNA repair. J Immunol. (2014) 192:5695-702. doi: $10.4049 /$ jimmunol.1303297
166. Crawford G, Hayes MD, Seoane RC, Ward S, Dalessandri T, Lai C, et al. Epithelial damage and tissue gammadelta $\mathrm{T}$ cells promote a unique tumor-protective IgE response. Nat Immunol. (2018) 19:859-70. doi: 10.1038/s41590-018-0161-8

167. Gebhardt T, Whitney PG, Zaid A, Mackay LK, Brooks AG, Heath WR, et al. Different patterns of peripheral migration by memory CD4+ and CD8 $+\mathrm{T}$ cells. Nature (2011) 477:216-9. doi: 10.1038/nature10339

168. Zaid A, Mackay LK, Rahimpour A, Braun A, Veldhoen M, Carbone FR, et al. Persistence of skin-resident memory $\mathrm{T}$ cells within an epidermal niche. Proc Natl Acad Sci USA. (2014) 111:5307-12. doi: 10.1073/pnas.1322292111

169. Puttur FK, Fernandez MA, White R, Roediger B, Cunningham AL, Weninger $\mathrm{W}$, et al. Herpes simplex virus infects skin gamma delta $\mathrm{T}$ cells before Langerhans cells and impedes migration of infected Langerhans cells by inducing apoptosis and blocking E-cadherin downregulation. J Immunol. (2010) 185:477-87. doi: 10.4049/jimmunol.0904106

170. Mueller SN, Zaid A, Carbone FR. Tissue-resident $T$ cells: dynamic players in skin immunity. Front Immunol. (2014) 5:332. doi: 10.3389/fimmu.2014.00332

171. Kawai K, Suzuki H, Tomiyama K, Minagawa M, Mak TW, Ohashi PS. Requirement of the IL-2 receptor beta chain for the development of Vgamma3 dendritic epidermal T cells. J Invest Dermatol. (1998) 110:961-5. doi: 10.1046/j.1523-1747.1998.00214.x

172. De Creus A, Van Beneden K, Stevenaert F, Debacker V, Plum J, Leclercq G. Developmental and functional defects of thymic and epidermal $\mathrm{V}$ gamma 3 cells in IL-15-deficient and IFN regulatory factor-1-deficient mice. $J$ Immunol. (2002) 168:6486-93. doi: 10.4049/jimmunol.168.12.6486

173. Kadow S, Jux B, Zahner SP, Wingerath B, Chmill S, Clausen BE, et al. Aryl hydrocarbon receptor is critical for homeostasis of invariant gammadelta T cells in the murine epidermis. J Immunol. (2011) 187:3104-10. doi: 10.4049/jimmunol.1100912

174. Li Y, Innocentin S, Withers DR, Roberts NA, Gallagher AR, Grigorieva $\mathrm{EF}$, et al. Exogenous stimuli maintain intraepithelial lymphocytes via aryl hydrocarbon receptor activation. Cell. (2011) 147:629-40. doi: 10.1016/j.cell.2011.09.025

175. Park SL, Zaid A, Hor JL, Christo SN, Prier JE, Davies B, et al. Local proliferation maintains a stable pool of tissue-resident memory T cells after antiviral recall responses. Nat Immunol. (2018) 19:183-91. doi: 10.1038/s41590-017-0027-5

176. Goodman T, Lefrancois L. Expression of the gamma-delta T-cell receptor on intestinal CD8+ intraepithelial lymphocytes. Nature (1988) 333:855-8. doi: $10.1038 / 333855 \mathrm{a} 0$

177. Lefrancois L, Puddington L. The role of the thymus in intestinal intraepithelial T-cell development. Ann N Y Acad Sci. (1996) 778:36-46.

178. Bandeira A, Mota-Santos T, Itohara S, Degermann S, Heusser C, Tonegawa $\mathrm{S}$, et al. Localization of gamma/delta $\mathrm{T}$ cells to the intestinal epithelium is independent of normal microbial colonization. J Exp Med. (1990) 172:23944.

179. Bandeira A, Itohara S, Bonneville M, Burlen-Defranoux O, Mota-Santos T, Coutinho A, et al. Extrathymic origin of intestinal intraepithelial lymphocytes bearing T-cell antigen receptor gamma delta. Proc Natl Acad Sci USA, (1991) 88:43-7.

180. Di Marco Barros R, Roberts NA, Dart RJ, Vantourout P, Jandke A, Nussbaumer O, et al. Epithelia Use Butyrophilin-like Molecules to Shape Organ-Specific gammadelta T Cell Compartments. Cell (2016) 167:203-18 e17. doi: 10.1016/j.cell.2016.08.030

181. Laky K, Lefrancois L, von Freeden-Jeffry U, Murray R, Puddington L. The role of IL-7 in thymic and extrathymic development of TCR gamma delta cells. J Immunol. (1998) 161:707-13.

182. Laky K, Lefrancois L, Lingenheld EG, Ishikawa H, Lewis JM, Olson $\mathrm{S}$, et al. Enterocyte expression of interleukin 7 induces development of gammadelta T cells and Peyer's patches. J Exp Med. (2000) 191:1569-80. doi: 10.1084/jem.191.9.1569

183. Takagaki Y, DeCloux A, Bonneville M, Tonegawa S. Diversity of gamma delta T-cell receptors on murine intestinal intra-epithelial lymphocytes. Nature (1989) 339:712-4. doi: 10.1038/339712a0

184. Zhao H, Nguyen H, Kang J. Interleukin 15 controls the generation of the restricted $\mathrm{T}$ cell receptor repertoire of gamma delta intestinal intraepithelial lymphocytes. Nat Immunol. (2005) 6:1263-71. doi: 10.1038/ni1267 
185. Shin S, El-Diwany R, Schaffert S, Adams EJ, Garcia KC, Pereira P, et al. Antigen recognition determinants of gammadelta $T$ cell receptors. Science (2005) 308:252-5. doi: 10.1126/science. 1106480

186. Kunisawa J, Kurashima Y, Higuchi M, Gohda M, Ishikawa I, Ogahara I, et al. Sphingosine 1-phosphate dependence in the regulation of lymphocyte trafficking to the gut epithelium. J Exp Med. (2007) 204:2335-48. doi: 10.1084/jem.20062446

187. Wurbel MA, Malissen M, Guy-Grand D, Meffre E, Nussenzweig MC, Richelme M, et al. Mice lacking the CCR9 CC-chemokine receptor show a mild impairment of early $\mathrm{T}$ - and B-cell development and a reduction in Tcell receptor gammadelta(+) gut intraepithelial lymphocytes. Blood (2001) 98:2626-32. doi: 10.1182/blood.V98.9.2626

188. Chennupati V, Worbs T, Liu X, Malinarich FH, Schmitz S, Haas JD, et al. Intra- and intercompartmental movement of gammadelta $\mathrm{T}$ cells: intestinal intraepithelial and peripheral gammadelta $\mathrm{T}$ cells represent exclusive nonoverlapping populations with distinct migration characteristics. J Immunol. (2010) 185:5160-8. doi: 10.4049/jimmunol.1001652

189. Guy-Grand D, Vassalli P, Eberl G, Pereira P, Burlen-Defranoux O, Lemaitre F, et al. Origin, trafficking, and intraepithelial fate of gut-tropic T cells. J Exp Med. (2013) 210:1839-54. doi: 10.1084/jem.20122588

190. Jensen KD, Shin S, Chien YH. Cutting edge: Gammadelta intraepithelial lymphocytes of the small intestine are not biased toward thymic antigens. J Immunol. (2009) 182:7348-51. doi: 10.4049/jimmunol.0900465

191. Lodolce JP, Boone DL, Chai S, Swain RE, Dassopoulos T, Trettin S, et al. IL-15 receptor maintains lymphoid homeostasis by supporting lymphocyte homing and proliferation. Immunity (1998) 9:669-76.

192. Kennedy MK, Glaccum M, Brown SN, Butz EA, Viney JL, Embers $\mathrm{M}$, et al. Reversible defects in natural killer and memory CD8 T cell lineages in interleukin 15-deficient mice. J Exp Med. (2000) 191:771-80. doi: 10.1084/jem.191.5.771

193. Yu Q, Tang C, Xun S, Yajima T, Takeda K, Yoshikai Y. MyD88dependent signaling for IL-15 production plays an important role in maintenance of CD8 alpha alpha TCR alpha beta and TCR gamma delta intestinal intraepithelial lymphocytes. J Immunol. (2006) 176:6180-5. doi: 10.4049/jimmunol.176.10.6180

194. Fahrer AM, Konigshofer Y, Kerr EM, Ghandour G, Mack DH, Davis MM, et al. Attributes of gammadelta intraepithelial lymphocytes as suggested by their transcriptional profile. Proc Natl Acad Sci USA. (2001) 98:10261-6. doi: $10.1073 /$ pnas. 171320798

195. Lefrancois L, Goodman T. In vivo modulation of cytolytic activity and Thy1 expression in TCR-gamma delta + intraepithelial lymphocytes. Science (1989) 243:1716-8.

196. Swamy M, Abeler-Dorner L, Chettle J, Mahlakoiv T, Goubau D, Chakravarty $\mathrm{P}$, et al. Intestinal intraepithelial lymphocyte activation promotes innate antiviral resistance. Nat Commun. (2015) 6:7090. doi: 10.1038/ncomms8090

197. Ismail AS, Behrendt CL, Hooper LV. Reciprocal interactions between commensal bacteria and gamma delta intraepithelial lymphocytes during mucosal injury. J Immunol. (2009) 182:3047-54. doi: 10.4049/jimmunol.0802705

198. Edelblum KL, Shen L, Weber CR, Marchiando AM, Clay BS, Wang $\mathrm{Y}$, et al. Dynamic migration of gammadelta intraepithelial lymphocytes requires occludin. Proc Natl Acad Sci USA. (2012) 109:7097-102. doi: 10.1073/pnas.1112519109

199. Malinarich FH, Grabski E, Worbs T, Chennupati V, Haas JD, Schmitz S, et al. Constant TCR triggering suggests that the TCR expressed on intestinal intraepithelial gammadelta $\mathrm{T}$ cells is functional in vivo. Eur J Immunol. (2010) 40:3378-88. doi: 10.1002/eji.201040727

200. Ridaura VK, Bouladoux N, Claesen J, Chen YE, Byrd AL, Constantinides $\mathrm{MG}$, et al. Contextual control of skin immunity and inflammation by Corynebacterium. J Exp Med. (2018) 215:785-99. doi: 10.1084/jem.20171079

201. Fleming C, Cai Y, Sun X, Jala VR, Xue F, Morrissey S, et al. Microbiotaactivated CD103(+) DCs stemming from microbiota adaptation specifically drive gammadeltaT17 proliferation and activation. Microbiome (2017) 5:46. doi: 10.1186/s40168-017-0263-9

202. Veldhoen M. Interleukin 17 is a chief orchestrator of immunity. Nat Immunol. (2017) 18:612-21. doi: 10.1038/ni.3742

203. Arunachalam P, Ludewig P, Melich P, Arumugam TV, Gerloff C, Prinz I, et al. CCR6 (CC Chemokine Receptor 6) Is Essential for the Migration of Detrimental Natural Interleukin-17-Producing gammadelta T Cells in Stroke. Stroke (2017) 48:1957-65. doi: 10.1161/STROKEAHA.117.0 16753

204. Shichita T, Sugiyama Y, Ooboshi H, Sugimori H, Nakagawa R, Takada I, et al. Pivotal role of cerebral interleukin-17-producing gammadeltaT cells in the delayed phase of ischemic brain injury. Nat Med. (2009) 15:946-50. doi: 10.1038/nm.1999

205. Gelderblom M, Weymar A, Bernreuther C, Velden J, Arunachalam P, Steinbach K, et al. Neutralization of the IL-17 axis diminishes neutrophil invasion and protects from ischemic stroke. Blood. (2012) 120:3793-802. doi: 10.1182/blood-2012-02-412726

206. Belkaid Y, Hand TW. Role of the microbiota in immunity and inflammation. Cell. (2014) 157:121-41. doi: 10.1016/j.cell.2014.03.011

207. Mair F, Joller S, Hoeppli R, Onder L, Hahn M, Ludewig B, et al. The NFkappaB-inducing kinase is essential for the developmental programming of skin-resident and IL-17-producing gammadelta T cells. Elife (2015) 4:e10087. doi: 10.7554/eLife.10087

208. McKenzie DR, Kara EE, Bastow CR, Tyllis TS, Fenix KA, Gregor CE, et al. IL-17-producing gammadelta $\mathrm{T}$ cells switch migratory patterns between resting and activated states. Nat Commun. (2017) 8:15632. doi: $10.1038 /$ ncomms 15632

209. Dechanet J, Merville P, Berge F, Bone-Mane G, Taupin JL, Michel P, et al. Major expansion of gammadelta T lymphocytes following cytomegalovirus infection in kidney allograft recipients. J Infect Dis. (1999) 179:1-8. doi: $10.1086 / 314568$

210. Lafarge X, Merville P, Cazin MC, Berge F, Potaux L, Moreau JF, et al. Cytomegalovirus infection in transplant recipients resolves when circulating gammadelta $\mathrm{T}$ lymphocytes expand, suggesting a protective antiviral role. $J$ Infect Dis. (2001) 184:533-41. doi: 10.1086/322843

211. Puig-Pey I, Bohne F, Benitez C, Lopez M, Martinez-Llordella M, Oppenheimer F, et al. Characterization of gammadelta $\mathrm{T}$ cell subsets in organ transplantation. Transpl Int. (2010) 23:1045-55. doi: 10.1111/j.1432-2277.2010.01095.x

212. Prinz I, Thamm K, Port M, Weissinger EM, Stadler M, Gabaev I, et al. Donor Vdelta1+ gammadelta $\mathrm{T}$ cells expand after allogeneic hematopoietic stem cell transplantation and show reactivity against CMV-infected cells but not against progressing B-CLL. Exp Hematol Oncol. (2013) 2:14. doi: 10.1186/2162-3619-2-14

213. Fornara C, Lilleri D, Revello MG, Furione M, Zavattoni M, Lenta E, et al. Kinetics of effector functions and phenotype of virus-specific and gammadelta $\mathrm{T}$ lymphocytes in primary human cytomegalovirus infection during pregnancy. J Clin Immunol. (2011) 31:1054-64. doi: 10.1007/s10875-011-9577-8

214. Ehl S, Schwarz K, Enders A, Duffner U, Pannicke U, Kuhr J, et al. A variant of SCID with specific immune responses and predominance of gamma delta T cells. J Clin Invest. (2005) 115:3140-8. doi: 10.1172/JCI 25221

215. de Villartay JP, Lim A, Al-Mousa H, Dupont S, Dechanet-Merville J, Coumau-Gatbois E, et al. A novel immunodeficiency associated with hypomorphic RAG1 mutations and CMV infection. J Clin Invest. (2005) 115:3291-9. doi: 10.1172/JCI25178

216. Vermijlen D, Brouwer M, Donner C, Liesnard C, Tackoen M, Van Rysselberge $\mathrm{M}$, et al. Human cytomegalovirus elicits fetal gammadelta T cell responses in utero. J Exp Med. (2010) 207:807-21. doi: 10.1084/jem.20090348

217. Khairallah C, Netzer S, Villacreces A, Juzan M, Rousseau B, Dulanto $\mathrm{S}$, et al. gammadelta $\mathrm{T}$ cells confer protection against murine cytomegalovirus (MCMV). PLoS Pathog. (2015) 11:e1004702. doi: 10.1371/journal.ppat.1004702

218. Sell S, Dietz M, Schneider A, Holtappels R, Mach M, Winkler TH. Control of murine cytomegalovirus infection by gammadelta T cells. PLoS Pathog. (2015) 11:e1004481. doi: 10.1371/journal.ppat.1004481

219. Wilk MM, Misiak A, McManus RM, Allen AC, Lynch MA, Mills KHG. Lung CD4 Tissue-Resident Memory T Cells Mediate Adaptive Immunity Induced by Previous Infection of Mice with Bordetella pertussis. J Immunol. (2017) 199:233-43. doi: 10.4049/jimmunol.1602051

220. Constant P, Davodeau F, Peyrat MA, Poquet Y, Puzo G, Bonneville M, et al. Stimulation of human gamma delta $\mathrm{T}$ cells by nonpeptidic mycobacterial ligands. Science. (1994) 264:267-70. 
221. Fournie JJ, Bonneville M. Stimulation of gamma delta $\mathrm{T}$ cells by phosphoantigens. Res Immunol. (1996) 147:338-47.

222. Morita CT, Mariuzza RA, Brenner MB. Antigen recognition by human gamma delta $\mathrm{T}$ cells: pattern recognition by the adaptive immune system. Springer Semin Immunopathol. (2000) 22:191-217. doi: $10.1007 / \mathrm{s} 002810000042$

223. Hoft DF, Brown RM, Roodman ST. Bacille Calmette-Guerin vaccination enhances human gamma delta $\mathrm{T}$ cell responsiveness to mycobacteria suggestive of a memory-like phenotype. J Immunol. (1998) 161:1045-54.

224. Bertotto A, Spinozzi F, Gerli R, Bassotti G, Forenza N, Vagliasindi C, et al. Peripheral blood gamma delta T cells in human listeriosis. Acta Paediatr. (1995) 84:1434-5.

225. Jouen-Beades F, Paris E, Dieulois C, Lemeland JF, Barre-Dezelus V, Marret $\mathrm{S}$, et al. In vivo and in vitro activation and expansion of gammadelta $\mathrm{T}$ cells during Listeria monocytogenes infection in humans. Infect Immun. (1997) 65:4267-72.

226. Munk ME, Elser C, Kaufmann SH. Human gamma/delta T-cell response to Listeria monocytogenes protein components in vitro. Immunology (1996) 87:230-5.

227. Begley M, Gahan CG, Kollas AK, Hintz M, Hill C, Jomaa H, et al. The interplay between classical and alternative isoprenoid biosynthesis controls gammadelta T cell bioactivity of Listeria monocytogenes. FEBS Lett. (2004) 561:99-104. doi: 10.1016/S0014-5793(04)00131-0

228. Ohga S, Yoshikai Y, Takeda Y, Hiromatsu K, Nomoto K. Sequential appearance of gamma/delta- and alpha/beta-bearing $\mathrm{T}$ cells in the peritoneal cavity during an i.p. infection with Listeria monocytogenes. Eur J Immunol. (1990) 20:533-8. doi: 10.1002/eji.1830200311

229. Skeen MJ, Ziegler HK. Induction of murine peritoneal gamma/delta $\mathrm{T}$ cells and their role in resistance to bacterial infection. J Exp Med. (1993) 178:971-84.

230. Matsuzaki G, Hiromatsu K, Yoshikai Y, Muramori K, Nomoto K. Characterization of T-cell receptor gamma delta $\mathrm{T}$ cells appearing at the early phase of murine Listeria monocytogenes infection. Immunology. (1993) 78:22-7.

231. Nakamura T, Matsuzaki G, Nomoto K. The protective role of T-cell receptor Vgammal+ T cells in primary infection with Listeria monocytogenes. Immunology (1999) 96:29-34.

232. Roark CE, Vollmer MK, Campbell PA, Born WK, O’Brien RL. Response of a gamma delta $+\mathrm{T}$ cell receptor invariant subset during bacterial infection. $J$ Immunol. (1996) 156:2214-20.

233. Roark CL, Aydintug MK, Lewis J, Yin X, Lahn M, Hahn YS, et al. Subset-specific, uniform activation among $\mathrm{V}$ gamma 6/V delta $1+$ gamma delta T cells elicited by inflammation. J Leukoc Biol. (2004) 75:68-75. doi: $10.1189 /$ jlb.0703326

234. Hamada S, Umemura M, Shiono T, Hara H, Kishihara K, Tanaka K, et al. Importance of murine Vdeltalgammadelta $\mathrm{T}$ cells expressing interferon-gamma and interleukin-17A in innate protection against Listeria monocytogenes infection. Immunology (2008) 125:170-7. doi: 10.1111/j.1365-2567.2008.02841.x

235. Sun X, Shibata K, Yamada H, Guo Y, Muta H, Podack ER, et al. CD30L/CD30 is critical for maintenance of IL-17A-producing gammadelta $\mathrm{T}$ cells bearing Vgamma6 in mucosa-associated tissues in mice. Mucosal Immunol. (2013) 6:1191-201. doi: 10.1038/mi.2013.18

236. Meeks KD, Sieve AN, Kolls JK, Ghilardi N, Berg RE. IL-23 is required for protection against systemic infection with Listeria monocytogenes. $J$ Immunol. (2009) 183:8026-34. doi: 10.4049/jimmunol.0901588

237. Hamada S, Umemura M, Shiono T, Tanaka K, Yahagi A, Begum MD, et al. IL-17A produced by gammadelta $\mathrm{T}$ cells plays a critical role in innate immunity against listeria monocytogenes infection in the liver. J Immunol. (2008) 181:3456-63. doi: 10.4049/jimmunol.181.5.3456

238. Tramonti D, Andrew EM, Rhodes K, Newton DJ, Carding SR. Evidence for the opposing roles of different gamma delta $\mathrm{T}$ cell subsets in macrophage homeostasis. Eur J Immunol. (2006) 36:1729-38. doi: 10.1002/eji.200635959

239. Dalton JE, Pearson J, Scott P, Carding SR. The interaction of gamma delta T cells with activated macrophages is a property of the $\mathrm{V}$ gamma 1 subset. $J$ Immunol. (2003) 171:6488-94. doi: 10.4049/jimmunol.171.12.6488

240. Dalton JE, Howell G, Pearson J, Scott P, Carding SR. Fas-Fas ligand interactions are essential for the binding to and killing of activated macrophages by gamma delta T cells. J Immunol. (2004) 173:3660-7. doi: 10.4049/jimmunol.173.6.3660

241. Andrew EM, Newton DJ, Dalton JE, Egan CE, Goodwin SJ, Tramonti $\mathrm{D}$, et al. Delineation of the function of a major gamma delta $\mathrm{T}$ cell subset during infection. J Immunol. (2005) 175:1741-50. doi: 10.4049/jimmunol.175.3.1741

242. Skeen MJ, Ziegler HK. Activation of gamma delta T cells for production of IFN-gamma is mediated by bacteria via macrophage-derived cytokines IL-1 and IL-12. J Immunol. (1995) 154:5832-41.

243. Skeen MJ, Rix EP, Freeman MM, Ziegler HK. Exaggerated proinflammatory and Th1 responses in the absence of gamma/delta $\mathrm{T}$ cells after infection with Listeria monocytogenes. Infect Immun. (2001) 69:7213-23. doi: 10.1128/IAI.69.12.7213-7223.2001

244. Newton DJ, Andrew EM, Dalton JE, Mears R, Carding SR. Identification of novel gammadelta $\mathrm{T}$-cell subsets following bacterial infection in the absence of Vgammal + T cells: homeostatic control of gammadelta T-cell responses to pathogen infection by Vgamma1+ T cells. Infect Immun. (2006) 74:1097-105. doi: 10.1128/IAI.74.2.1097-1105.2006

245. Hasegawa T, Tanaka T, Yoshikai Y. The appearance and role of gamma delta T cells in the peritoneal cavity and liver during primary infection with Listeria monocytogenes in rats. Int Immunol. (1992) 4:1129-36.

246. Kimura Y, Tomida S, Matsumoto Y, Hiromatsu K, Yoshikai Y. Evidence for the early recruitment of $\mathrm{T}$-cell receptor gamma delta $+\mathrm{T}$ cells during rat listeriosis. Immunology. (1996) 87:21-8.

247. Wollert T, Pasche B, Rochon M, Deppenmeier S, van den Heuvel J, Gruber AD, et al. Extending the host range of Listeria monocytogenes by rational protein design. Cell (2007) 129:891-902. doi: 10.1016/j.cell.2007. 03.049

248. Sheridan BS, Pham QM, Lee YT, Cauley LS, Puddington L, Lefrancois L. Oral infection drives a distinct population of intestinal resident memory CD8(+) $\mathrm{T}$ cells with enhanced protective function. Immunity (2014) 40:747-57. doi: 10.1016/j.immuni.2014.03.007

249. Romagnoli PA, Fu HH, Qiu Z, Khairallah C, Pham QM, Puddington L, et al. Differentiation of distinct long-lived memory CD4 T cells in intestinal tissues after oral Listeria monocytogenes infection. Mucosal Immunol. (2017) 10:520-30. doi: 10.1038/mi.2016.66

250. Gentles AJ, Newman AM, Liu CL, Bratman SV, Feng W, Kim D, et al. The prognostic landscape of genes and infiltrating immune cells across human cancers. Nat Med. (2015) 21:938-45. doi: 10.1038/nm.3909

251. Zocchi MR, Costa D, Vene R, Tosetti F, Ferrari N, Minghelli S, et al. Zoledronate can induce colorectal cancer microenvironment expressing BTN3A1 to stimulate effector gammadelta T cells with antitumor activity. Oncoimmunology (2017) 6:e1278099. doi: 10.1080/2162402X.2016.1278099

252. Zhou DY, Qin J, Huang J, Wang F, Xu GP, Lv YT, et al. Zoledronic acid inhibits infiltration of tumor-associated macrophages and angiogenesis following transcatheter arterial chemoembolization in rat hepatocellular carcinoma models. Oncol Lett. (2017) 14:4078-84. doi: 10.3892/ol.2017.6717

253. Braza MS, Klein B. Anti-tumour immunotherapy with Vgamma9Vdelta2 T lymphocytes: from the bench to the bedside. Br J Haematol. (2013) 160:12332. doi: 10.1111/bjh. 12090

254. Wrobel P, Shojaei H, Schittek B, Gieseler F, Wollenberg B, Kalthoff $\mathrm{H}$, et al. Lysis of a broad range of epithelial tumour cells by human gamma delta T cells: involvement of NKG2D ligands and T-cell receptorversus NKG2D-dependent recognition. Scand J Immunol. (2007) 66:320-8. doi: 10.1111/j.1365-3083.2007.01963.x

255. Todaro M, D'Asaro M, Caccamo N, Iovino F, Francipane MG, Meraviglia S, et al. Efficient killing of human colon cancer stem cells by gammadelta T lymphocytes. J Immunol. (2009) 182:7287-96. doi: 10.4049/jimmunol.0804288

256. Gomes AQ, Correia DV, Grosso AR, Lanca T, Ferreira C, Lacerda JF, et al. Identification of a panel of ten cell surface protein antigens associated with immunotargeting of leukemias and lymphomas by peripheral blood gammadelta T cells. Haematologica (2010) 95:1397-404. doi: 10.3324/haematol.2009.020602

257. Gertner-Dardenne J, Castellano R, Mamessier E, Garbit S, Kochbati E, Etienne A, et al. Human Vgamma9Vdelta2 $\mathrm{T}$ cells specifically recognize and kill acute myeloid leukemic blasts. J Immunol. (2012) 188:4701-8. doi: 10.4049/jimmunol.1103710 
258. Berglund S, Gaballa A, Sawaisorn P, Sundberg B, Uhlin M. Expansion of Gammadelta T Cells from Cord Blood: A Therapeutical Possibility. Stem Cells Int. (2018) 2018:8529104. doi: 10.1155/2018/8529104

259. Capsomidis A, Benthall G, Van Acker HH, Fisher J, Kramer AM, Abeln Z, et al. Chimeric antigen receptor-engineered human gamma delta $T$ cells: enhanced cytotoxicity with retention of cross presentation. Mol Ther. (2018) 26:354-65. doi: 10.1016/j.ymthe.2017.12.001

260. Meraviglia S, Eberl M, Vermijlen D, Todaro M, Buccheri S, Cicero G, et al. In vivo manipulation of Vgamma9Vdelta2 $\mathrm{T}$ cells with zoledronate and lowdose interleukin-2 for immunotherapy of advanced breast cancer patients. Clin Exp Immunol. (2010) 161:290-7. doi: 10.1111/j.1365-2249.2010.04167.x

261. Capietto AH, Martinet L, Fournie JJ. Stimulated gammadelta T cells increase the in vivo efficacy of trastuzumab in HER-2+ breast cancer. J Immunol. (2011) 187:1031-8. doi: 10.4049/jimmunol.1100681

262. Kabelitz D, Wesch D, Pitters E, Zoller M. Characterization of tumor reactivity of human $\mathrm{V}$ gamma $9 \mathrm{~V}$ delta 2 gamma delta $\mathrm{T}$ cells in vitro and in SCID mice in vivo. J Immunol. (2004) 173:6767-76. doi: 10.4049/jimmunol.173.11.6767

263. D’Asaro M, La Mendola C, Di Liberto D, Orlando V, Todaro M, Spina $\mathrm{M}$, et al. $\mathrm{V}$ gamma $9 \mathrm{~V}$ delta $2 \mathrm{~T}$ lymphocytes efficiently recognize and kill zoledronate-sensitized, imatinib-sensitive, and imatinib-resistant chronic myelogenous leukemia cells. J Immunol. (2010) 184:3260-8. doi: 10.4049/jimmunol.0903454

264. Sugai S, Yoshikawa $T$, Iwama $T$, Tsuchiya $N$, Ueda $N$, Fujinami $N$, et al. Hepatocellular carcinoma cell sensitivity to Vgamma9Vdelta2 T lymphocyte-mediated killing is increased by zoledronate. Int J Oncol. (2016) 48:1794-804. doi: 10.3892/ijo.2016.3403

265. Zumwalde NA, Haag JD, Sharma D, Mirrielees JA, Wilke LG, Gould $\mathrm{MN}$, et al. Analysis of Immune Cells from Human Mammary Ductal Epithelial Organoids Reveals Vdelta2 + T Cells That Efficiently Target Breast Carcinoma Cells in the Presence of Bisphosphonate. Cancer Prev Res. (2016) 9:305-16. doi: 10.1158/1940-6207.CAPR-15-0370-T

266. Yoshikawa T, Takahara M, Tomiyama M, Nieda M, Maekawa R, Nakatsura T. Large-scale expansion of gammadelta $\mathrm{T}$ cells and peptide-specific cytotoxic $\mathrm{T}$ cells using zoledronate for adoptive immunotherapy. Int J Oncol. (2014) 45:1847-56. doi: 10.3892/ijo.2014.2634

267. Nakazawa T, Nakamura M, Park YS, Motoyama Y, Hironaka Y, Nishimura $\mathrm{F}$, et al. Cytotoxic human peripheral blood-derived gammadeltaT cells kill glioblastoma cell lines: implications for cell-based immunotherapy for patients with glioblastoma. J Neurooncol. (2014) 116:31-9. doi: 10.1007/s11060-013-1258-4

268. Kaiser AD, Assenmacher M, Schroder B, Meyer M, Orentas R, Bethke U, et al. Towards a commercial process for the manufacture of genetically modified $\mathrm{T}$ cells for therapy. Cancer Gene Ther. (2015) 22:72-8. doi: 10.1038/cgt.2014.78

269. Musso A, Catellani S, Canevali P, Tavella S, Vene R, Boero S, et al. Aminobisphosphonates prevent the inhibitory effects exerted by lymph node stromal cells on anti-tumor Vdelta $2 \mathrm{~T}$ lymphocytes in non-Hodgkin lymphomas. Haematologica (2014) 99:131-9. doi: 10.3324/haematol.2013.097311

270. Fowler DW, Copier J, Dalgleish AG, Bodman-Smith MD. Zoledronic acid causes gammadelta $\mathrm{T}$ cells to target monocytes and downmodulate inflammatory homing. Immunology. (2014) 143:539-49. doi: $10.1111 /$ imm. 12331
271. Welton JL, Morgan MP, Marti S, Stone MD, Moser B, Sewell AK, et al. Monocytes and gammadelta $\mathrm{T}$ cells control the acute-phase response to intravenous zoledronate: insights from a phase IV safety trial. J Bone Miner Res. (2013) 28:464-71. doi: 10.1002/jbm r.1797

272. Kalyan S, Chandrasekaran V, Quabius ES, Lindhorst TK, Kabelitz D. Neutrophil uptake of nitrogen-bisphosphonates leads to the suppression of human peripheral blood gammadelta T cells. Cell Mol Life Sci. (2014) 71:2335-46. doi: 10.1007/s00018-013-1495-x

273. Bansal P, Sonnenberg A. Pancreatitis is a risk factor for pancreatic cancer. Gastroenterology (1995) 109:247-51.

274. Chiesa Fuxench ZC, Shin DB, Ogdie Beatty A, Gelfand JM. The Risk of Cancer in Patients With Psoriasis: A Population-Based Cohort Study in the Health Improvement Network. JAMA Dermatol. (2016) 152:282-90. doi: 10.1001/jamadermatol.2015.4847

275. Jess T, Rungoe C, Peyrin-Biroulet L. Risk of colorectal cancer in patients with ulcerative colitis: a meta-analysis of population-based cohort studies. Clin Gastroenterol Hepatol. (2012) 10:639-45. doi: 10.1016/j.cgh.2012. 01.010

276. Brockmann L, Giannou AD, Gagliani N, Huber S. Regulation of TH17 Cells and Associated Cytokines in Wound Healing, Tissue Regeneration, and Carcinogenesis. Int J Mol Sci. (2017) 18:1033. doi: 10.3390/ijms180 51033

277. Tse SW, Radtke AJ, Espinosa DA, Cockburn IA, Zavala F. The chemokine receptor CXCR6 is required for the maintenance of liver memory $\mathrm{CD} 8(+) \quad \mathrm{T}$ cells specific for infectious pathogens. J Infect Dis. (2014) 210:1508-16. doi: 10.1093/infdis/ jiu281

278. Devaud C, Bilhere E, Loizon S, Pitard V, Behr C, Moreau JF, et al. Antitumor activity of gammadelta $\mathrm{T}$ cells reactive against cytomegalovirus-infected cells in a mouse xenograft tumor model. Cancer Res. (2009) 69:3971-8. doi: 10.1158/0008-5472.CAN-08-3037

279. Devaud C, Rousseau B, Netzer S, Pitard V, Paroissin C, Khairallah C, et al. Anti-metastatic potential of human Vdeltal $(+)$ gammadelta $\mathrm{T}$ cells in an orthotopic mouse xenograft model of colon carcinoma. Cancer Immunol Immunother. (2013) 62:1199-210. doi: 10.1007/s00262-0131402-1

280. Henault J, Riggs JM, Karnell JL, Liarski VM, Li J, Shirinian L, et al. Selfreactive IgE exacerbates interferon responses associated with autoimmunity. Nat Immunol. (2016) 17:196-203. doi: 10.1038/ni.3326

Conflict of Interest Statement: The authors declare that the research was conducted in the absence of any commercial or financial relationships that could be construed as a potential conflict of interest.

Copyright (๑) 2018 Khairallah, Chu and Sheridan. This is an open-access article distributed under the terms of the Creative Commons Attribution License (CC BY). The use, distribution or reproduction in other forums is permitted, provided the original author(s) and the copyright owner(s) are credited and that the original publication in this journal is cited, in accordance with accepted academic practice. No use, distribution or reproduction is permitted which does not comply with these terms. 